\title{
Muhasebe Bilgi Sisteminde Kurumsal Bilgelik Anlayışı*
}

\author{
Ali ALAGÖZ** \\ Metehan ORTAKARPUZ ${ }^{* * *}$
}

\section{ÖZET}

Değişen koşullara ve belirsizliklere karşı, karar mekanizmalarını destekleyen, strateji ve politikalara katkı sağlayan, işletme ihtiyaçlarına yönelik etkin raporlar sunan muhasebe bilgi sistemi için, optimal bilgi yönetimi olarak kabul edilen kurumsal bilgelik anlayışı, önemli bir yenilenme hareketi olarak görülmektedir. Bu çalışmada muhasebe bilgi sistemi, bilgi yönetimi ve kurumsal bilgelik anlayışı bakışı ile ele alınmış, söz konusu alanlara ait bileşenler ve kriterler üzerinde incelemeler yapılmıştır. Teorik olarak araştırılan konunun, uygulamadaki karşılığını görmek üzere kurumsal bilgi yönetim altyapısına sahip işletmelere anket uygulanmıştır. Anket verileri istatistiksel analizlere tabi tutulmuş, kurumsal bilgelik anlayışı ile muhasebe bilgi sistemi ilişkisi değerlendirilmiştir.

Anahtar Kelimeler: Kurumsal Bilgelik, Bilgi Yönetimi, Muhasebe Bilgi Sistemi, Yönetim Muhasebesi

JEL Sınıflandırması: M41, M49, M15.

\section{Corporate Wisdom Understanding In Accounting Information System}

\section{ABSTRACT}

An understanding of corporate wisdom, considered as optimal information management, is seen as an important renewal movement for the accounting information system, which supports the decision-making mechanisms, contributes to strategy and politics, and provides effective reports on business needs against changing conditions and uncertainties. In this study, accounting information system is handled with the view of the elements of knowledge management and corporate wisdom, and the components and criteria of on these areas are examined. In order to see effectiveness in practice of the subject examined theoretically, a questionnaire was applied to the enterprises having institutional information management infrastructure. The data's of questionnaire were subjected to statistical analysis and the relationship between corporate wisdom and accounting information system was evaluated.

Keywords: Corporate Wisdom, Knowledge Management, Accounting Information System, Management Accounting.

Jel Classification: M41, M49, M15

\footnotetext{
* Çalışmada kullanılan teorik kısım Ali ALAGÖZ danışmanlığında Metehan ORTAKARPUZ tarafından hazırlanmış olan "Rekabetçi ve Sürdürülebilir Büyüme Hedefli İşletmeler İçin Kurumsal Bilgelik Anlayışında Muhasebe Bilgi Sistemi: Bilge Muhasebe Modeli Önerisi” isimli doktora tezinden derlenmiştir.

** Prof. Dr. Ali Alagöz, Selçuk Üniversitesi, aalagozs@selcuk.edu.tr

*** Öğr. Gör. Metehan Ortakarpuz, Selçuk Üniversitesi, mortakarpuz@selcuk.edu.tr
} 


\section{GİRiş}

Geleneksel bilgi yönetiminin, rekabetçi ve sürdürülebilir büyüme hedefli işletmelerin ihtiyaçlarını karşılamada yetersiz kalması yüzünden günümüz şartlarına uygun hale getirilmesi, bilgi üretimi ve kullanımında, deneyim, zeka ve yargılardan yararlanmak, kurum kültürü ve demokrasisini sağlamak, bilgi sistem ve teknoloji kullanımlarını arttırmak, vb. kriterler bilgi yönetimini optimal fayda düzeyine yükseltecek unsurlardır. Bilgi yönetimi için arzulanan bu fayda düzeyine, sadece insana has olduğu düşünülen bilgelik erdeminin kurumsal yapıya entegre edilmesiyle elde edilecek kurumsal bilgelik anlayışıyla ulaşılacağı öngörülmektedir. Kurumsal bilgelik bu doğrultuda geliştirilmiş ve literatürde yerini almış yeni bir anlayıştır. Değişen koşullara uygun işletme ihtiyaçlarına yönelik etkin raporlar ancak, kurumsal bilgelik anlayışı sayesinde, formal ve informal olarak üretilen bilgilerle oluşturulabilir.

Bilgi yönetimindeki yapısal ve teknolojik gelişmelerden diğer bilgi sistemleri gibi muhasebe bilgi sistemi de etkilenmektedir. Bu paralelde muhasebe bilgi sisteminin yönetim muhasebesi alanında geliştirilmesi, işletmenin günümüz rekabetçilik ve sürdürülebilirlik şartlarına uygun hale gelmesi için oldukça önemlidir. Söz konusu gelişmenin sağlanabilmesi için muhasebe fonksiyonunun, optimuma ulaşmış bir bilgi yönetim alt yapısı üzerinde olması gerekmektedir. Günümüzde muhasebe bilgi sisteminden beklenen, veri girişi, kayıt ve sınıflandırma işlemlerinden ziyade, bilgi üretimi ve yönetimi, teknolojiye kullanımı ile kontrol sistemlerinin planlanması ve işletilmesinde aktif rol oynamasıdır. Karar vericilerin gereksinimleri doğrultusunda, bilgi teknolojileri altyapısını kullanmak suretiyle, istenilen nitelikte bilgi üretmek, zaman, hız, yüksek iletişim ve esneklik elde etmek, çalışanların tecrübeleri, yetenekleri, eğitimleri, sosyal çevreleri, sezgi ve öngörüleri gibi kişisel özelliklerinden yararlanmak üzere, kurumsal bilgelik anlayışına sahip bilgi yönetimi kapsamında muhasebe bilgi sistemini geliştirmesi hedeflenmelidir. Bilgi verimliliğinin ve değerinin arttırılması, örtük bilginin ortaya çıkarılması ve informal bilgiye dayalı raporlamalar için muhasebe bilgi sistemi alt yapısı bu doğrultuda güçlendirilmelidir.

Bu çalışmada muhasebe bilgi sistemi, bilgi yönetimi ve kurumsal bilgelik anlayışı unsurları ile ele alınmıştır. Bilgi yönetiminin bileşenleri aynı zamanda muhasebe bilgi sisteminin bileşenleri olarak kabul edilmiştir. Bileşenler kapsamlı bir şekilde incelenirken, kurumsal bilgelik anlayışının kriterleri ile etkileşimi açıklanmıştır. Teorik olarak araştırılan konunun, uygulamadaki karşılığını görmek üzere kurumsal bilgi yönetimi ve muhasebe bilgi sistemi altyapısına sahip işletmelere, kurumsal bilgelik ve muhasebe bilgi sistemi başlıklı anket uygulanmıştır. Anket ile elde edilen veriler, muhasebe bilgi sistemi bileşenleri ve kurumsal bilgelik anlayışı kriterlerinin değerlendirilmesi, aralarındaki ilişkinin tespit edilmesi maksadıyla gerekli istatistiksel analizlere tabi tutulmuştur. Genel değerlendirme sonuç bölümünde yapılmıştır.

\section{KURUMSAL BİLGELIKK}

Kurumsal bilgelik, kurumun beklenmedik durumlara akılcı tepkiler verebilmesini, kurumun mevcut ve yeni bilgisini yönetmesini, tüm paydaşlarına karşı, iyi, ahlâklı ve örnek davranışları sergilemesini ifade etmektedir (Kaygısız ve Çağlıyan, 2014: 228). Kurumsal bilgelik, bireysel bilgilerin toplamı, paylaşımı, bütünleştirilmesi ve stratejik eylemler için kurumsal yapı, kültür, liderlik gibi sosyal süreçlerde kullanılmasıdır (Kessler, 2006: 297). 
Kurumsal bilgelik tecrübeyle biriktirilen ve işyerinde günlük öğrenilenlere eklenen çok önemli organizasyon kaynağıdır (Karakoçak, 2007: 25). Fakat kurumun doğal faaliyetleriyle ilgili yapılan işlemler, karar alıcılar için bir esin kaynağı değildir, kurumsal bilgelik zamanla bu işlemlerin birbiriyle bağlantılarını bularak ve değişikliklerini gözleyerek gelişir (Thierauf ve Hoctor, 2006: 5). Bilgelik, görünen durumun ötesine bakmak, olağanüstü faktörleri tanımak ve sıradışı sonuçlarını tahmin etmek için deneyimden doğan sezgisel yeteneği kullanmay1 gerektirir (Thierauf, 1999: 9). Aslında kurumsal bilgelikle hedeflenen noktalardan birisi de budur. Kurumun gelecekte olan1, bugünden tahmin etmesi optimum fayday1 sağlayacak kararları alabilmesidir. Kurumsal bilgelik, sadece optimizasyon ve iş zekası şeklinde bilgiyi bir araya getiren şemsiye değil, aynı zamanda optimal ve bilge kararlara ulaşmada karar vericilere yardımcı olmak için yollar sağlayan bir yönetim kavramıdır. (Thierauf ve Hoctor, 2006: 10).

\subsection{Kurumsal Bilgelik Anlayışının Kriterleri}

Kurumsal bilgelik, optimum bilgi yönetimi veya bireysel bilgeliğin kurumsal boyutu olarak değerlendirilmektedir. Her iki bakış açısında da ulaşılacak olan, kurumsal bilgelik seviyesi için bilgi yönetiminin geliştirilmesi ve kurum içinde bilgelik anlayışına uygun yapıların tesis edilmesidirr. Literatürde yer alan tanımlardan yola çıkılarak kurumsal bilgelik anlayışı hakkında genel bir çıkarım yapılabilir.

Bierly ve arkadaşları (2000), dönüşümcü liderlik, kurum kültürü ve yapısı ve bilgi transferi olarak üç temel kavramdan bahsetmiş ve bunların kurumsal bilgeliğe etkilerini ayrıntılı olarak ortaya koymuştur. Hays (2007), bilge düşünce ve eylemin yönünü iş ahlakı, sürdürülebilirlik, dönüşümcü liderlik, kurumsal vatandaşlık ve sosyal sorumluluk ile işyeri demokratikleşmesi gibi filizlenen disiplinlerin merkezi olarak belirtmiştir. Spiller (2011), kurumda "maneviyat, kültür, sosyal ve çevresel etkileşimlerle bilgeliğin varlığına dikkat çekmiştir. Limas (2004), kurumsal bilgeliğin varlığının, kurumun etik ortamını, kurumsal vatandaşlığı, kurumsal sadakati, esnekliği ve iyileşmeleri olumlu etkilediğini savunmuştur. Intezari ve Pauleen (2014), kurumsal bilgelik doğrultusunda etik, ahlaki ve pratik erdemleri bilgi yönetimi ile kesiştirmiştir. Thierauf ve Hoctor (2006), Gupta (2003), Chong ve Choi (2006), bilgi yönetim sürecinden hareketle, bilgi oluşturulması ve dağıtımında örgütsel öğrenmeyi ve öğrenen örgüt kavramlarının önemini belirtmiştir. Popadiuk ve Choo, (2006) ile Karakoçak (2007) ise, yenilikçilik ve değişime ayak uydurma konularının optimum bilgi yönetimi için gerekliliğine değinmiştir. Göz ardı edilemeyecek önemde bulunan ve etkin bilgi yönetimi anahtarlarından sayılan çalışan katılımı ile ilgili Ryan ve Prybuyo (2001), Moffett ve arkadaşları, (2003), Çağlıyan ve Kaygısız (2014), Davenport vd., (1998), kurumsal bilgelik ile örtüşen çalışmalar yapmışlardır.

Tüm bu çalışmalar ve ortak görüşler sentezlendiğinde kurumsal bilgelik anlayışını oluşturan temel kavramlar "dönüşümcü liderlik", "kurum kültürü ve yapisl”, "bilgi transferi”, "öğrenen örgüt ve örgütsel öğrenme”, "kurumsal demokrasi”, "kurumsal sürdürülebilirlik”, "kurumsal yenilikçilik ve değişim”, olarak sıralanabilir.

\subsubsection{Dönüşümcü Liderlik}

Dönüşümcü liderlik anlayışına göre, lider izleyicilerin ihtiyaçlarını, değer yargılarını değiştirir. Dönüşümcü lider organizasyonlarda, değişim ve yenilenmeyi gerçekleştirerek üstün 
performansa ulaştıran kişidir (Ceylan, vd, 2005: 33). Bennis (1989)'e göre dönüşümcü liderlik, vizyonunu gerçekleştirmek için, izleyenleri yetkilendirme, güçlendirme ve dağıttığı yetkiyi, gücü eylem birliğine dönüştürme yeteneğidir (Erçetin, 2000: 60). Bass (1990)’ a göre dönüşümcü liderliğin dört bileşeni vardır (Bierly vd., 2000: 610):

1. Karizma; vizyon ve misyon duygusu sağlar, gurur aşılar, saygı ve güven kazandırır.

2. Ilham; yüksek beklentileri iletir, basit sembollerle girişime odaklanır, önemli amaçları basit yöntemlerle ifade eder.

3. Entelektüel teşvik; zekayı, rasyonelliği ve dikkatli problem çözmeyi teşvik eder.

4. Bireyselleştirilmiş düşünce; kişilere önem verir, her çalışana bireysel yaklaşır, antrenörlük yapar, tavsiyede bulunur.

Özellikleri bakımından dönüşümcü liderliğin bilgeliğe en yakın liderlik tipi olduğunu söylemek yanlış olmaz. Bilge kişiler gibi dönüşümcü liderlerde de eğitim ve özverili çaba ile izleyicilerine bilgeliği yaymak ve aşılamakta bir öğretmendir.

\subsubsection{Kurum Kültürü ve Yapısı}

Kurum kültürü, bir kurumun içindeki insanların davranışlarını yönlendiren normlar, davranışlar, değerler, inançlar ve alışkanlıklar sistemidir (Dinçer, 1992:271). Kurum kültürü, kurum içinde neyin yapılması gerektiğini ve nelerin değerli olduğunu bireye anlatan, kurumu koruyan ve güçlendiren, çalışan grubunun da birlikteliğini sağlayan bir bağlayıcıdır (Sezgin ve Bulut, 2013: 183). Kurumun üyelerinin tutum ve davranışlarını şekillendiren ve onlara rehberlik eden bir kontrol ve duygu oluşturma mekanizmasıdır (Scott, 2006: 498).

Bilgelik, kurumsal amaçlar doğrultusundaki yükümlülüklerin dikkate alındığı uygun düzenlilikler sayesinde kurumsallaşabilir. Bu anlamda, etkili sonuçlara ulaşmak ve bireysel bilgeliği organizasyonel bilgeliğe dönüştürmenin yolunu açmak için kılavuz yapılar ya da ön programlar aktif edilir (Bierly vd., 2000: 612). Torbert (1991), bilgi yönetiminin gelişimini desteklemek için bir kurum kültürünün özgürlükçü bir yapıya sahip olması gerekliliğini savunmuştur. Özgürlükçü yapılar örgütsel öğrenmeyi sınırlayan engellerin üstesinden gelmenin araçlarıdır. Bu yapıların temel amacı bilgeliğe ulaşma yolunda çalışanların disiplin ve özgürlük derecelerini genişletmek için onları güçlendirmektedir (Bierly vd., 2000: 612).

\subsubsection{Bilgi Transferi}

Bir kurumda birçok bilgi sahibi insan olabilir fakat kurumun kendisinin bilgi sahibi (bilge) ve yetenekli (dağıtılmış bilgiden yararlanan) olabilmesi, bilgi ve yeteneklerin etkili bir şekilde kurumun birimleri arasındaki ilgililerine ve paydaşlara transfer edilmesiyle mümkün olacaktır (Hays, 2007: 24).

Bilgi transferi kurumsal bilgeliğin gelişimi için gerekli olan temel mekanizmanın bir parçasıdır. Kurumsal bilgelik, bireyin bilgiyi toplaması, transfer etmesi, bütünleştirmesi, bilgiyi kullanarak karar vermesi ve kurumun yapısal kültürü ve rutinleri gibi sosyal süreçleri seçmesi ve bu özel bilgiyi yine stratejik eylemlerde ve özel durumlarda kullanabilmesidir. (Bierly vd., 2000: 597). Kurumsal bilgelik, karar merkezini çalıştıran ve öğrenmeyi teşvik eden etkili bilgi transferi ve iletişim sistemi aracılığıyla etkin olabilir (Bierly vd., 2000: 612). 


\subsection{4. Öğrenen Örgüt ve Örgütsel Öğrenme}

Kurumsal bilgelik, bilgi yönetimi ve örgütsel öğrenme uygulamaları ile prensipleri üzerine inşa edilmiştir ancak bu kavramları aşarak öğrenmeyi teşvik etme, anlayış, bağlılık ve "doğru olanı yapma" değerleri için hedef oluşturmaktadır (Hays, 2007: 17). Kurumsal bilgeliğin var olabilmesi için örgüt içerisinde öğrenme felsefesinin yerleşmesi önemli bir zorunluluktur.

Bilgi yönetimi sürecinde, örgütsel öğrenme temel olarak bilginin yaratılmasına, öğrenen örgüt ise bilginin erişimi, depolanması, aktarılması ve uygulanmasına olanak sağlayan olgudur (Gupta, 2003: 293). Örgütsel öğrenme, veri, enformasyon, bilgi ve bilgeliğin birbiriyle ilişkilendirilmesi, geliştirilmesi ve genişletilmesidir (Bierly vd., 2000: 597). Öğrenen örgüt, örgütsel öğrenme ile bilgi yönetimini birleştiren bir ortam yaratan örgüttür. Öğrenen örgüt, bilgiyi oluşturmada, elde etmede ve aktarmada, örgütsel davranış1, yeni bilgiye göre uyarlamada yeteneği olan örgüttür (Garvin, 1993: 80).

\subsubsection{Kurumsal Demokrasi}

Kurumsal anlamda demokrasi, kurumları bütün olarak etkileyen kararların kurumun tüm üyelerince alınması ve karar alma mekanizmasında, tüm tarafların eşit haklara sahip olması idealini oluşturur (Çelik, 2007: 32). Kurumsal demokrasi, otoriter olmayan liderlik tarzından, karar mekanizmasında küçük çaplı çalışan katılımı ve daha geniş anlamda çalışanların kendilerini yönettikleri teşebbüslere varana kadar unsurları içinde barındıran bir kavramdır (Smith, 1976: 276). Hoffman (2002) kurumsal demokrasinin temelinde eşitlik, katılım, tartışma ve fikir birliği, paylaşılan örgüt değerlerine destek ve insanlığın ortak değerlerine karşı duyulan bir saygı varlığını ifade etmiştir (Coşan ve Gülova, 2014: 233).

\subsubsection{Kurumsal Sürdürülebilirlik}

Kurumsal sürdürülebilirlik yeni ve gelişen bir işletme yönetimi paradigması olarak kabul edilmektedir. Genel anlamda işletme faaliyetlerinin sadece ekonomik boyutlarını değil, sosyal ve çevresel boyutlarını da göz önünde bulundurmayı hedefleyen bir kavramdır. Wilson (2003), kurumsal sürdürülebilirliğin işletmenin büyümesi ve kârlılığı için önemli olduğunu kabul ederken, aynı zamanda işletmenin, çevresel koruma, ekonomik gelişme, sosyal hak ve adalet gibi sürdürülebilir kalkınmayla ilgili toplumsal amaçları izlemesi gerektirdiğini vurgulamıştır (Tüm, 2014: 59). Dyllick ve Hockerts (2002) ise kurumsal sürdürülebilirliği, ekolojik ve sosyal sürdürülebilirliğin bir karması olarak ifade ederken, kurumların kısa vadeli kazançlar yerine, uzun vadeli kazanca yönelmeleri gerektiğini açıklamıştır (Kuşat, 2012: 229).

\subsubsection{Kurumsal Yenilikçilik ve Değişim}

Organizasyonun düşünce gücünü kullanarak yeni fikirler oluşturan ve süreci destekleyen bilgi yönetimi ve yenilik arasında yakın bir ilişkinin varlığı söz konusudur (Karakoçak, 2007: 126). Kurumsal bilgelik anlayışında bilgi yönetimi, yenilikçiliğe uygun kurumsal yapı ve sürekli gelişimi zorlayan iş süreçlerinin desteklendiği ve geniş ölçüde tüm çalışanların katılımıyla yeni bilginin yaratıldığı bir yapıya kavuşmaktadır. Kurumsal bilgelik ve kurumsal yenilikçilik birbirlerini destekleyen ve tamamlayıcı kavramlar olup aralarındaki doğrusal bir ilişki söz konusudur. Bu ilişki kurum hangi kavramı stratejik hedefleri 
doğrultusunda merkeze konumlandırırsa konumlandırsın bir diğerini de paralel hedef olarak belirlemesini gerektirmektedir.

\subsection{Kurumsal Bilgelik Anlayışı Bakışıyla Bilgi Yönetimi}

Literatürde bilgi yönetiminin geliştirilmesi ve görece optimum düzeye getirilmesi ile ilgili sayısız çalışma yer almaktadır. Fakat tam olarak kurumsal bilgelik anlayışı ile geliştirilmiş bir çalışma bulunmamaktadır. Buna karşılık Lee ve Kim (2001)'in yapmış oldukları çalışma, konunun bütünlüğüne en yakın çalışma olarak görülmektedir. Lee ve Kim (2001); bilgi yönetiminin sadece grupların öğrenimine sunmak için geliştirilmiş bir elektronik belgeleme yöntemi olmadığını bunun yerine içerisinde insanları, organizasyon yapısı, kültür ve bilgi teknolojileri gibi diğer kaynakları da içeren bir paradigma olduğunu ortaya koymuşlardır (Lee ve Kim, 2001: 300-301). Bu görüş için Grant (1996), Nonaka (1994) Pentland (1995) ve Tsoukas (1996)'den esinlenmişlerdir.

Lee ve Kim (2001)'e göre bilgi yönetiminin bütünleşik çerçevesi, yönetsel ve teknik boyutlarıyla, dört temel bileşenden ve aralarındaki çekirdek yönetsel ve teknik faktörlerden oluşmaktadır. Bilgi yönetiminin dört bileşeni "bilgi yönetim süreci" (ki bu bileșen bilgi kaynaklarını temsil etmektedir), "bilgi teknolojileri", "bilgi çalışanları" ve "organizasyonel bilgi üretimi” dir. (Lee ve Kim, 2001: 301). Bu gerçekliği ortaya koyma üzere bilgi yönetimi bileșenlerini ayrı ayrı ele alan Liebeskind (1996), Spender (1996), Winter (1987), Demarest (1997), Wiig (1997), Romer (1999), Nonaka (1994), Brown ve Duguid (1991), Heumer Krogh ve Roos (1998), Krackhardt ve Hanson (1996), Davenport vd., (1998), Liebowitz ve Wilcox (1997), O'Leary (1998), Ruggles (1998), Day ve Glazor (1994), Garvin (1993), Hedlund (1994), Nonaka (1994), Quinn ve arkadaşları (1996), Lank, (1997), O'Dell ve Grayson (1998) ve Tampoe (1996) gibi yazarlardan çıkarımlar yapmışlardır.

Kurumsal bilgelik anlayışı dikkate alınarak, Lee ve Kim (2001)'in oluşturduğu bilgi yönetiminin bütünleşik çerçevesi geliştirilmiş, bilgi yönetiminin bileşenlerin ve sürece etki eden kriterlerin birbirleriyle etkileşimini gösteren şekil-1' çizilmiştir.

Şekil 1: Kurumsal Bilgelik Anlayışında Bilgi Yönetiminin Bütünleşik Çerçevesi

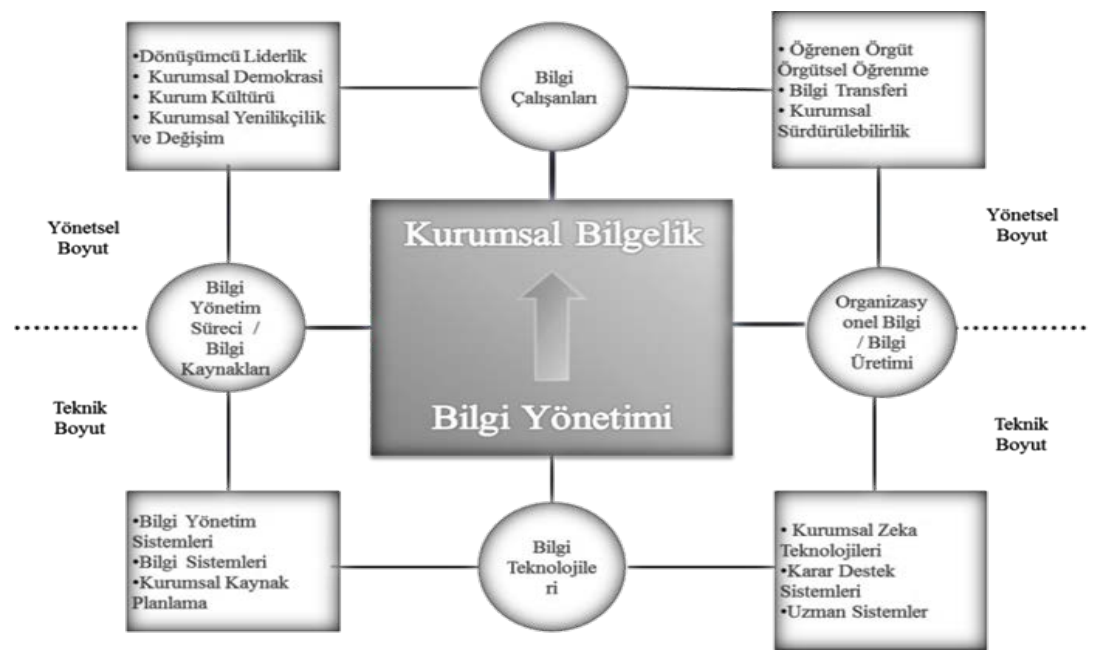

Kaynak: Lee ve Kim (2001)'in “Bilgi Yönetimi Bileşenleri ve Organizasyonel Yaklaşımlar” Şeklinden Geliştirilmiştir. 
Yönetsel boyutta bilgi yönetim süreci ve organizasyonel bilgi bileşenleri bilgi çalışanları bileşeni ile etkileşim içerisinde iken, teknik boyutta, bilgi teknolojileri bileşeniyle etkileşim içerisindedir. Kurumsal bilgelik anlayışı bilgi yönetimine yönetsel boyutta bir iyileştirme yapmaktadır. Kurumsal bilgelik anlayışının kriterleri, bilgi yönetiminde mevcut bilgi sürecinin geliştirilmesini ve bilgi kaynaklarının çeşitlenmesine imkan verirken, tecrübe, yorum ve sezgilerle nitelikli hale getirilmiş, bilgi kullanıcılarının beklentilerini karşılayacak düzeyde bilgi üretimi sağlanabilmektedir.

Teknik boyutta bilgi yönetiminin temel bileşeni bilgi teknolojisidir. Bilgi teknolojisi kullanımı bilgi yönetim sürecinde elde edilen bilgi kaynağından, organizasyonel bilgi üretimine kadar etkin bir araç olarak görülmektedir. Veri ve bilgi kaynağına ulaşmadan, nitelikli bilgi üretimine kadar olan süreçte sistemleri daha işlevsel hale getiren bir bileşendir. Diğer yandan bilgi kaynağının oluşturulması ve kullanılmasında, bilgi yönetim sistemleri, bilgi sistemleri ve kurumsal kaynak planlamaya, bilginin üretilmesinde ise kurumsal zeka teknolojileri, karar destek sistemleri ve uzman sistemlere ihtiyaç duyulmaktadır.

Yönetsel boyut ise, kurumsal bilgelik anlayışının bileşenlere daha etkin uygulanması gereken ve bilgi yönetiminde kurumsal bilgeliğin oluşmasını sağlayacak alandır. Bu alanda bilgi çalışanları bileşeni etkileşim halinde olduğu diğer iki bileşimin merkezinde yer almaktadır. Bilgi yönetim süreci ile bilgi kaynakları ve organizasyonel bilgi üretimi bileşeni arasındaki etkileşim tamamıyla kurumsal bilgelik anlayışını oluşturan unsurlar ile geliştirilmiştir. Buna göre, bilgi çalışanlarına, bilgi yönetim sürecinde ulaşılan bilgi kaynağının elde edilmesi ve kullanılmasında, dönüşümcü liderlik, kurumsal demokrasi, kurum kültürü ve altyapısı, kurumsal yenilikçilik ve değişim unsurlarının tesis edildiği bir altyapı hazırlanmalıdır. Organizasyonel bilgi üretiminde ise öğrenen örgüt veya örgütsel ögrenme, bilgi transferi ve kurumsal sürdürülebilirlik unsurlarının tesis edilmesi gerekmektedir.

\section{MUHASEBE BİLGİ SİSTEMINDE KURUMSAL BİLGELİK ANLAYIŞI}

Muhasebenin üstlendiği sorumluluk gereği, muhasebe bilgi sisteminin periyodik ve nitelikli bilgi üretme zorunluluğu bulunmaktadır. Paydaşlar, devlet, işletmeler vb. bilgi kullanıcıları için vergileme, denetim ve finansal raporlamayı kapsayan önceden biçimlendirilmiş bilgiler üretilmektedir. Muhasebe bilgi sisteminde kullanılan yazılımlar muhasebenin standart işleyişi ve yasal yükümlülükler doğrultusunda geliştirilmiştir. Dolayısıyla muhasebe bilgi sisteminin, daha çok işletme dışına, formal bir yapıda raporlama yapabilmek üzere dizayn edildiğini söylemek yanlış olmaz. Bunun yanında özellikle işletme içi bilgi kullanıcılarına yönelik, nitelikli ve değer yaratan bilgiler ve bu paraleldeki farklı raporlama tipleri, genellikle formal bir yapıda bilgi üreten sistemlerde tamamen mümkün olmamaktadır. Diğer yandan muhasebe bilgileri nitelik olarak yön değiştirmektedir. Stratejik ve değer yaratacak nitelikte katkı sağlayan, faaliyetlerin ve etkinliğin ön plana çıktığı, kalite ve müşteri tatmininin baz alındığı, sürdürülebilir işletme yapısına uygun muhasebe bilgilerinin önemi artmıştır. Bu bağlamda muhasebe bilgi sisteminden geleneksel yapısının dışında informal bilgi üretmesi beklenmektedir. Beklenen ve talep edilen informal bilgi, kurumsal zeka temeline dayanan, beklenmedik durumlara sezgisel ve akılcı yaklaşım getiren, yoğun çalışan katkısı ve entelektüel zeka ile üretilen, zamansız (periyodik olmayan), hızlı, basit ve esnek bilgidir. 
Bilgi yönetiminin "bilgi kaynakları, bilgi teknolojileri, bilgi çalışanları ve bilgi üretimi” temel bileşenleri aynı zamanda muhasebe döngüsünün de unsurlarıdır. Muhasebe bilgi sisteminin yukarıda bahsedilen gerekçelere dayandırılarak geliştirilmesi için temel bileşenlerinin kurumsal bilgelik anlayışı ile ele alınması doğru bir yol olacaktır. Buna göre ilk bileşen muhasebe bilgi yönetim sürecinde işletmenin bilgi kaynakları olarak kabul edilen dinamik yetenekleridir. Muhasebe bilgi sisteminin entelektüel sermayesi olan dinamik yetenekler, insan sermayesi, sosyal sermaye ve yapısal sermaye olarak açıklanmaktadır. İkinci bileşen ve muhasebe bilgi kaynaklarının işlenmesinde önemli rol oynayan bilgi teknolojileridir. Operasyonel, taktiksel ve stratejik yönetim düzeylerinde çalışan muhasebe bilgi sistemi bilgi çalışanları ise bu anlayışta üçüncü bileşeni oluşturmaktadır. Muhasebe bilgi sisteminde bilgi üretimi bileşeni ise örtük bilginin açığa çıkarılması, informal bilgi üretimi ve raporlama kavramlarını kapsamaktadır. $\mathrm{Bu}$ doğrultuda kurumsal bilgelik anlayışında muhasebe bilgi sisteminin bileşenleri Şekil-2'deki çizimde gösterilmiştir.

Şekil 2: Kurumsal Bilgelik Anlayışında Muhasebe Bilgi Sisteminin Bileşenleri

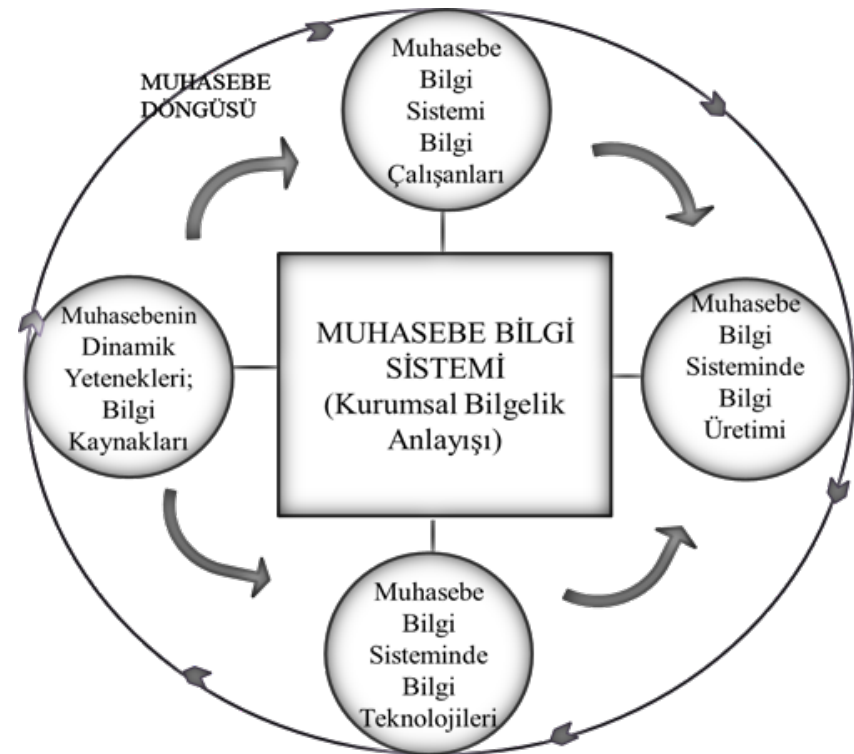

\subsection{Muhasebe Bilgi Yönetim Sürecinde Dinamik Yetenekler: Bilgi Kaynakları}

Bilgi kaynağı denince akla ilk olarak bilgi yönetim sistemlerinin somut ve nicel girdileri olan ve bilgi hiyerarşisinin en alt tabakalarında yer alan veri ve enformasyonlar gelmektedir. Fakat bilgi yönetiminde kaynak olarak görülmesi gerekenler, söz konusu veri ve enformasyonların elde edildiği yerler ve süreçlerdir. Bilgi kaynaklarının zenginleştirilmesi ve kurumsal ihtiyaçlar doğrultusunda nitelikli hale getirilmesi bilgi yönetim sürecinin gelişmesine imkan sağlamaktadır. Bilgi üretiminin hammaddeleri olan veri ve enformasyonlara bazen somut, bazen de soyut kaynakların çalıştırılması sonucu ulaşılabilmektedir. Kurumun bilgi kaynakları aynı zamanda sahip olduğu yetenekleri arasında kabul edilmekte ve diğer işletmelerden kendisini ayıran en önemli özelliği arasında gösterilmektedir.

Barney (1991)'e göre ise, taklit ve ikame edilemeyen yetenekler, kurumun değerli kaynaklarıdır ve rekabet avantajı sağlamaktadır. Bu kaynaklar, tesis, teçhizat, konum gibi 
fiziksel olabileceği gibi, işgücü, yönetim, eğitim, tecrübe kültür ve itibar gibi insani ve örgütsel yetenekleridir (Turan, 2014: 152). Söz konusu kaynaklar her işletmede az ya da çok bulunmakta ama her işletme bu kaynakları optimum düzeyde kullanamamaktadır. Kısacası yetenekler işletme kaynaklarını kullanma becerisi olarak ifade edilebilir (Turan, 2014: 153). Bilgi yönetim sürecinde işletme kaynaklarının dinamik ve ihtiyaçlara cevap verecek ölçüde olması beklenir. Yeteneklerin var olması bilgi kaynağını kullanma anlamına gelmeyecektir. Önemli olan bu yeteneklerin dinamik olması ve değişen koşullara uygun kaynaklar hazırlayabilmesidir.

İşletmenin dinamik yeteneklerini, kurumsal bilgelik anlayışının kriterleriyle örtüşen ve bu anlayışın işletme bünyesinde tesis edilmesine yardımcı olan önemli bir kaynak olarak görmek mümkündür. Öyle ki, kurumsal bilgelik anlayışının unsurlarından, dönüşümcü liderlik, kurumsal yenilikçilik ve değişim, kurumsal sorumluluk, bilgi transferi ile öğrenen örgüt ve örgütsel öğrenme kavramları, dinamik yetenekler olarak entelektüel sermayeler ile doğrudan ilişkilidir. Dinamik yetenekler, yeni ürün ve süreç geliştirme kabiliyeti, fiziksel veya kapasitesel yetenekleri olarak somut yetenekler olabileceği gibi soyut yetenekler de olabilir. Bunlar, geliştirme ve değişim için gerekli olan beceri, bilgi, uzmanlık, kaynak ve kalifiye hakları gibi kişisel ve belli bir grup tarafından temsil edilen, rakipler tarafından kolaylıkla takip edilemez ayırt edici işletme kimliğidir. Bu kimlik işletmenin görünmeyen varlıkları olarak belirtilen entelektüel sermayesidir (Alagöz vd., 2013: 1-2). Entelektüel sermaye statik bir varlıktan çok, işletmenin gereksinimlerine uygulandığında katma değer yaratan dinamik bir unsurdur. İşletmenin süreçlerini, teknolojilerini, buluşlarını, iş görenlerinin yeteneklerini, müşterileri, satıcıları ve işletmenin ilgi grupları hakkındaki bilgilerini kapsayan çatı bir kavramdır. Bu kapsam işletmenin insan sermayesi, sosyal sermayesi ve yapısal sermayesi başlıklarıyla gruplandırılır.

Muhasebe fonksiyonu ne kadar teknoloji ile donatılırsa donatılsın bilgi üretimi, mesleki yeterlilik ve uzmanlık, liderlik, yorum ve yargı gereksinimleri, risk alma, problem çözme, değişim ve teknik bilgi konularında insan sermayesine en çok ihtiyaç duyan işletme alanlarındandır. Dolayısıyla insan sermayesi, muhasebe bilgi yönetim sürecinde, işletmenin rekabetçilik, yenilenme, sürdürülebilirlik hedefleri doğrultusunda vazgeçilmez ve dinamik bir yetenektir. Diğer yandan bilgi yönetiminin bilgi çalışanları bileşeni tam da insan sermayesini tarif etmektedir. Bilgi çalışanlarının, bilgi kaynakları ve bilgi üretimi bileşenleriyle olan ilişkisinde, soyut olan insan sermayesi yeteneği yine aynı şekilde soyut olan kurumsal bilgelik anlayışının unsurları ile muhasebe bilgi yönetim sürecine katkı yapar hale gelebilir. Kurumsal bilgelik anlayışında bilgi yönetimi ve muhasebe fonksiyonunun vazgeçilmezi olan insan sermayesi ne kadar parlatılırsa o kadar işletme hedefleri doğrultusunda fayda sağlayacaktır.

Kurumsal bilgelik anlayışıyla hedeflenen kurumsal değişim ve yenilikçilik kriteri için değişen çevre koşullarının sürekli ve hızlı bir şekilde takip edilmesi önemlidir. Bu maksatla büyük resme bakma, yaratıcı düşünme, faaliyetlere konsantre olma, firsatları kullanma ve değişime ayak uydurma unsurlarının geliştirilmesi, bunun için de sosyal sermayenin güçlendirilmesi gerekmektedir. İşletmenin kurum dışından sağlayacağı bilgi kaynaklarının temelini sosyal sermaye oluşturmaktadır. Bilgi yönetim sürecinde müşterilerden, tedarikçilerden, işbirlikçilerden, sosyal ağlardan ve ilişkilerden sağlanan bilgilerin katkısı büyüktür. Özellikle muhasebe fonksiyonunun öngörü ve sorunlara hızlı çözüm önerileri sunabilme yeteneklerini kazanmasında sosyal sermaye oldukça etkilidir. Günümüzde sosyal 
sermaye kaynağından elde edilecek bilgilerin karar verme süreçlerine etki yapacak önemli muhasebe raporlarının içeriğinde bulunması beklenmektedir.

Kurumsal bilgelik anlayışında bilgi yönetiminin alt yapısı, yapısal sermaye unsurlarından oluşmaktadır. Bilgi yönetim sürecinde, kaynakların ve bilgi teknolojilerinin kullanımı ile bilgi üretimi bileşenleri için yapısal sermayenin kuvvetli olması gerekmektedir. Ayrıca bu sermayenin kurum çalışanları tarafından kabul edilmesi ve benimsenmesi gerekmektedir. Muhasebe fonksiyonunda insan sermayesi kadar yapisal sermayenin büyüklüğünü ve oldukça fazla hissedilen işletme dinamiklerinden biri olduğunu söylemek yanlış olmaz. Günümüzde ticari yazılımlardan, alt bilgi sistemlerine, kurumsal kaynak planlama ve kurumsal zeka uygulamalarına kadar bir çok bilgi teknolojisi yeteneği ile kurum kültürü ve felsefesi, işletme know-how'1 ve ticari anlayışı gibi soyut unsurlar yapısal sermayeye verilecek örneklerdendir. Dinamik bir muhasebe bilgi sisteminin oluşturulmasında örnek verilen yeteneklere sahip olunması artık bir zorunluluk haline gelmiştir.

\subsection{Muhasebe Bilgi Sisteminde Bilgi Teknolojileri}

Gelişen teknolojiler ile bilgi sistemleri ve kurumsal kaynak planlama altyapıları için daha kolay ve ucuz maliyetlerle büyük veri tabanları oluşturulabilmektedir. Bununla birlikte büyük veri tabanlarından, ihtiyaç duyulan anlamlı, kullanılabilir ve nitelikli bilgiye erişmek te güçleşmiştir. Bu nedenle aranılan bilgi için verileri eleyen, seçen, analiz eden, enformasyona ve bilgiye dönüştüren teknolojik altyapılar geliştirilmiştir. Geliştirilen bu teknolojilerle, verileri çeşitli istatiksel metotlarla analiz ederek, kurumların karar verme sürecinin etkinliğine ve yeni stratejiler geliştirmesine katkı sağlamaktadır. (Baykal, 2006: 96). Bu doğrultuda kurumsal zeka teknolojileri, karar destek sistemleri, ve uzman sistemler kurumsal bilgi altyapısında bilgi üretimi için geliştirilmiş bilgi teknolojisi kavramları olarak görülmektedir.

Bilgi teknolojileri, planlama, tahminleme, muhasebe kayıtlarının tutulması ve takibi, fatura düzenleme ve benzeri birçok finansal ve finansal olmayan faaliyetlerin daha kolay, daha seri ve daha hızlı yapılabilmesini sağlamaktadır. Bilgi teknolojilerinin bir sonucu olarak ortaya çıkan kurumsal zeka teknolojileri, kurumsal bilgi organizasyonlarında ve muhasebe bilgi sisteminde yer almaya ve artan teknoloji ile geliştirilen teknikleri kullanarak nitelikli bilgi üretimine katkı sağlamaya başlamıştır (Alagöz vd., 2014: 14). Muhasebe bilgi sisteminde, kullanıcıları tarafindan yönetilen kurumsal zeka modeli, elde edilen ve veri tabanında depolanıp, sınıflandırılan verileri, sisteme entegre edilen kurumsal zeka teknolojisi yöntemlerinin kullanılmasıyla analiz etmeyi sağlamaktadır. Kullanılacak zeka teknolojisi, istenen bilginin niteliğine göre kullanıcılar tarafından daha önceden tanımlanabileceği gibi, sistemin bu yönde geliştirilmesiyle otomatik olarak da seçilebilmektedir.

Kurumsal zeka teknolojileri içerinde yer alan veri madenciliği, muhasebe bilgi sistemine entegre edilebilen, verinin sunumu için toplama, sınıflandırma ve muhasebe analizi aşamaları neticesinde bilgi üretimi ve bilginin oluşturulmasına izin veren ve karar verme sürecini geliştiren önemli bir teknolojidir (Rahman, 2008: 23). Diğger bir teknik olan doğrusal planlama, muhasebe ve mali denetim faaliyetlerinde, işgücü ve kaynak planlamasına katkı sağlayacak önemli bir zeka teknolojisidir. Muhasebe kontrolü ve denetim faaliyetlerinde, varlıkların korunması, finansal kayıtların güvenilirliğini sağama ve kıymet hareketleri takibi ile finans, muhasebe ve diğer tüm konulardaki kontrollerin sıhhatinin, yine işletmede bu amaçla çalışan kişilerin iç denetim çalışmalarının ve bağımsız denetim faaliyetlerinin 
yürütülmesinde önemli bir en iyileme aracıdır. Sınıflandırma ve kümelenme yöntemleri kullanarak verinin sınıfını belirleyen ve veri ile ilgili geleceğe yönelik doğru bir tahmin yapılmasına yardımcı olan diğer bir zeka teknolojisi yöntemidir. $\mathrm{Bu}$ yöntemin en öne çıkan örnek uygulaması risk analizidir. Ayrıca sınıflandırma ve regresyon teknikleri normal eğilimlerden farklı verilerin açığa vurarak aykırı durumların tespitini sağlayabilir. Önemli bir zeka teknolojisi olan yapay sinir ağları tekniği de güçlü bir istatistiksel modelleme yöntemi olarak görülmektedir. Bu yöntem vasıtasıyla veri setindeki işlemler arasındaki ilişki tespit edilmekte ve bu işlemler sınıflandırmaya, değerlendirmeye, tahmin ve kontrol işlemlerine tabi tutulmaktadır. $\mathrm{Bu}$ özelliklerinden dolayı adli muhasebede hile tespitinde, finansal bilgi manipülasyonun tespitinde ve risk değerlemelerinde kullanım alanı bulmaktadır. Diğer bir zeka teknolojisi olan karar ağaçları tekniği özellikle proje değerlendirmeleri aşamasında, farklı alternatiflerin kıyaslanmasında ve çeşitli olası durumlarda nakit akımlarına ilişkin tespitler yapmada kullanılır. Böylece muhasebe bilgi sisteminin bütçeleme ve fizibilite çalışmalarına sağlayacağı bilgilerin nitelikli hale getirilmesi sağlanabilmektedir. Genetik algoritmalar, K-En yakın komşu, bellek temelli nedenleme, birliktelik kuralları, sapma testi vb. kurumsal zeka teknolojileri de muhasebe bilgi sistemi entegrasyonu ile müşteri, çalışan ilişkileri, risk analizi, hile denetimi ve karar alma gibi önemli konularda nitelikli bilgi elde edilebilmekte, doğru zamanda doğru kaynak ve işgücünün kullanılması, doğru işlere atanması gibi faaliyetlerin başarıyla sonuçlanmasına katkı sağlayarak, karı maksimize ederken, maliyetleri minimuma indirilebilmektedir.

Karar destek sistemleri, yönetim bilgi sistemlerinin karar verme süreçlerinde yetersiz kalması nedeniyle, bir üst bilgi sistemi aşaması olarak geliştirilmiş teknolojik sistemlerdir. Yönetsel kararların alınmasında karşılaşılan problemlerin artması üzerine yükselen rekabet ve bilgisayar teknolojilerindeki gelişmelerle karar destek sistemleri geliştirilmiştir. Geleneksel muhasebe anlayışında da karar vericilere sağlanan bilgi yeterli görülmediğinden karar destek sistemleri muhasebe bilgi sisteminin bir sonraki aşaması olarak ele alınmaktadır. Genel olarak muhasebe karar destek sistemlerini de fonksiyonunun sorumluluğunda kabul etmekte, muhasebe bilgi sistemi ile birlikte geliştirmeyi tercih etmektedir.

Uzman sistemler karar destek paradigması üzerine kurulan ama sisteme konuyla ilgili bilgi ve uzmanlığı da entegre eden bir kavram olarak doğmuştur. Uzman sistemler ile karar destek sistemlerinin fonksiyonelliğine muhakeme yeteneği eklenmesi, problemlerde çözüm önerileri getirebilmesi sağlanmaktadır. Muhasebe raporlarında uzmanlaşmış otoritenin görüş ve yorumlarının bilgisayar programına entegre edilmesiyle otonom karar vermeyi taklit eden uzman sistemler çeşitli durum ve koşulları da dikkate alır. Bu özelliği sayesinde daha önce tecrübe edilmiş ve çözümlenmiş problemlerin tekrarlanmasında çözüme ilişkin hızlı ve doğru sonuçlar alınabilmektedir. Yeni gelişecek olaylar ve problemlerle ilgili de uzman sistemler, ancak kullanıcılarının muhakeme içerikli bilgi tabanını zenginleştirmeleriyle mümkün olabilmektedir. $\mathrm{Bu}$ noktada muhasebe bilgi sistemi uzmanlarına, uzman sistemlerin kullanacağı veri ve bilgileri sürekli olarak sağlama ve geliştirme görevi düşmektedir. Muhasebe bilgi sisteminin stratejik planlama, bütçeleme, iş planları vb. konularda rolünün her geçen gün artması uzman sistemlerle olan ilişkisini de arttırmaktadır.

\subsection{Muhasebe Bilgi Sisteminde Bilgi Çalışanları}

Veri ve enformasyon gibi nispeten daha teknik ve somut kavramların aksine, bilgi, bireyin düşüncesinde bulunan, davranışlar ve ilişkiler sonucu ortaya çıkan daha değerli ve 
özel bir kavramdır. Bu özelliği ile bilginin bireylerden bağımsız olarak ele alınması mümkün değildir. Bilginin stratejik yönetimi, çevresel faktörlerin etkilerinden çok, organizasyon içinde yer alan önemli ilişkilerin yönetimi ve bilgi çalışanlarından kaynaklanan beceri ve kabiliyetlerin bir sonucu olarak görülmelidir (Barutçugil, 2002: 55). Bu nedenle işletme ölçeğinde bilgi yönetiminin en önemli unsurlarında birisi bilgi çalışanlarıdır. Bilgi çalışanları, ham verileri işlemekte ve bu veriler üzerine katma değer oluşturarak hem bilgi hem de strateji üretmektedirler.

Kurumsal bilgelik anlayışının muhasebe bilgi sistemi bileşenleri içerisinde en çok odaklandığı bileşen bilgi çalışanlarıdır. Kurumsal bilgelik anlayışının kurum kültürü ve yapısı, kurumsal demokrasi, ögrrenen örgüt ve örgütsel öğrenme gibi kriterleri, işletme amaçları doğrultusunda, bilgi çalışanlarının bilgi üretimine katkısını geliştirmeyi hedeflemektedirler. Ayrıca dönüşümcü liderlerin hedefinde bilgi çalışanları yer almaktadır. Kurumsal yenilikçiliğin ve değişim anlayışının var olabilmesi bilgi çalışanlarının süreçleri kabul etmesinden geçmektedir. Yine diğer yandan bilgi transferi ve paylaşımında en aktif görev alan bileşen bilgi çalışanlarıdır. Kurumsal sürdürülebilirlik hedefi ise, kurumsal sorumluluk ve vatandaşlığın bilgi çalışanları tarafindan benimsenmesi ile gerçekleşmektedir.

Bilgi çalışanlarının, bilgi yönetimi ve muhasebe bilgi sistemi içerisinde üstlendikleri roller, bilgi yönetim sistemi düzeylerine göre farklılık göstermektedir. Bu doğrultuda farklı fonksiyonlarda farklı yapılanmalara sahip bilgi sistemleri, genel olarak bilgi yönetimi içerisinde "alt yönetim (operasyonel)", “orta yönetim (taktiksel)” ve “üst yönetim (stratejik)”, işletme düzeyleri (Sürmeli, 2005: 29) olarak ele alınmalı ve bilgi çalışanları buna göre ayrılmalıdır. Muhasebe bilgi sisteminde veri işleme, depolama, sinıflandırma ve enformasyona dönüştürme işlemleri operasyonel bilgi düzeyine yönelik iken, bilgi oluşturma, raporlama ve bilgiyi kullanma işlemleri taktiksel düzeye yakındır. Stratejik düzeyde ise muhasebe bilgilerinin uzun vadeli ve stratejik amaçlar doğrultusunda kullanımı söz konusudur. Muhasebe bilgi sistemini bilgi yönetimi seviyelerine göre incelemek ve bilgi çalışanlarını bu ölçüde ele almak gerekir.

Operasyonel düzeyde yer alan bilgi çalışanları, bilgi üretimine alt yapı oluşturan, veriyi bilgi sistemlerinde kullanılması için tedarik eden ve işleyen, veri tabanını yöneten bilgi yönetim sürecinin iş̧̧ileridir. Yönetimde olmayan çalışanlar ile yöneticiler arasında bağlantı halkası olan bilgi işçileri işletmenin tüm fonksiyonlarında, ofis çalışanı, muhasebe sorumlusu, ofis yöneticisi birim amiri, takım lideri veya ustabaşı gibi görevler üstlenirler (Boundless, 2015: 1). Bu düzeydeki çalışanlar kısa vadeli planlar çerçevesinde bilgiyi kullanma, yorumlama ve yönetsel karar almadan uzak ofis otomasyon işlemleri ölçeğinde faaliyet gösterir. Bilgi sisteminin en alt düzey çalışanları bilgi işçileri, muhasebeye konu olan tüm işlerde süreci başlatan ilk kişilerdir. Üretilecek bilgi ve raporlar bilgi işçisinin faaliyetleri sonucu meydana gelecektir. Bilgi sistemlerinin teknoloji ile geliştirilmesine ve bilgi üretiminde otomasyonun artmasına rağmen bilgi işçileri bu sistemleri kullanan ve yönetenler olarak hala vazgeçilmez kişilerdir. Bu nedenle muhasebe bilgi işçisinin, işletmenin yasal yükümlülükleri çerçevesinde yürürlükteki mevzuata uygun yapısal ve formal kayıt yapması, işletme içi kullanıcılara yönelik verimli ve değer oluşturabilecek bilgi verileri ve enformasyonu elde etmesi ve teknolojiyi iyi kullanması gerekmektedir. Ayrıca bilgi işçisinin veri, bilgi, sistem ve teknoloji güvenliği noktasında da yeterli olması gerekmektedir. Bu doğrultuda muhasebe departmanında çalışan bilgi işçisinin itina ile seçilmesi, muhasebe alanında yeterli eğitimi almış olması önemlidir. Kurumsal bilgelik anlayışında bilgi işçisinin 
ilk olarak kurum kültürüne adaptasyonu sağlanmalıdır. Kurumun karakterize olmuş normları, inançları, değerleri çalışan tarafından benimsenmelidir. Bilgi işçisinin sahip olacağı aidiyet duygusu işletme menfaatleri doğrultusunda çalışmasına olanak sağlayacaktır. Kurumsal demokrasi de dönüşümcü liderlik ise, bilgi işçisini motive edecek diğer önemli unsurlar olacaktır. Çalışanın söz ve temsil hakkının olduğu adil bir anlayış, saygınlık, güven ve sorumluluğu beraberinde getirecektir. Bu kapsamda bir diğer unsurda öğrenen örgüt ve örgütsel öğrenmenin sağlanmasıdır. Öğrenme bireyde başlayacağı, geliştirilerek ortak amaçlar doğrultusunda örgüt seviyesinde kullanılacağı için, çalışanların öğrenmesinin örgütsel öğrenme için oldukça önemli olduğunu belirtmek gerekir. Bu doğrultuda bilgi çalışanlarının ögrenme ve eğitim faaliyetlerine sürekli devam edilmesi gerekmektedir.

Taktiksel düzeydeki bilgi çalışanları hem iç hem de dış bilgi ile ilgilenen bilgi yöneticileri olarak ifade edilmektedir. Genel müdürler, şube müdürleri, departman müdürleri, saha ve bölge sorumluları, proje yürütücüleri, mali müşavirler, mali denetçiler veya danışmanlar organizasyonda bilgi yöneticisi rolünü üstlenen bilgi çalışanı örnekleridir. $\mathrm{Bu}$ kişiler kendi bölümlerinin işlevinden dolayı üst yönetime karşı sorumlu kişilerdir. Bilgi yöneticisi taktiksel düzeyde inovatif zekayı temsil eder (Yaghoubi, vd., 2011: 1414). Yönetsel faaliyetlere katkı yapan, karar almada gerek duyulan bilgi, enformasyon yı̆̆ını içerisinden, bilgi yöneticisinin faaliyetleri sonucu çıkartılır. Bilgi yöneticisi, kurumsal zeka ile altyapısı güçlendirilmiş bilgi sistemleri ve karar destek sistemlerinden yararlanır. Taktiksel düzeyde finansal faaliyetlerin sonuçları ile muhasebe raporları analiz edilir. Yararlanılan sistemler sayesinde maliyet-hacim-kar (başa baş) analizleri, esnek bütçe uygulamaları, fiyatlandırma ve karlılık analizleri, satış regresyon analizleri ve miktar belirlemeleri vb. uygulamalar yürütülür. $\mathrm{Bu}$ düzeyde muhasebe bilgi sistemi, işletme dişı karar vericiler için finansal muhasebe, işletme içi kullanıcılar için yönetsel muhasebe, finansal tabloların analiz ve denetimi, vergi yükümlülüklerinin incelenmesi ile tüm muhasebe faaliyetlerinin kontrolü faaliyetlerini yürütür. Muhasebe bilgi sistemi faaliyetlerini yürüten muhasebeciler, finansal ve yönetim muhasebecileri, denetçiler, vergi uzmanları ve muhasebe müdürleri gibi taktiksel düzey bilgi yöneticileridir (Wilkinson vd., 2000).

Stratejik düzey bilgi sistemlerini kullanan bilgi çalışanları bilgi profesyonelleri olarak adlandırılmaktadır. Bilgi profesyonelleri bilgi yönetiminin en üst kademesinde yer alan üst düzey yöneticilerdir. Yönetim veya icra kurulu başkanı, başkan yardımcısı, üyeleri, koordinatörler ile CEO, CFO gibi C düzeyi üst düzey yöneticiler bilgi profesyonelleri olarak ifade edilmektedir (Boundless, 2015: 1). Bilgi profesyonelleri işletmenin geleceğini belirlemek için stratejik kararlar almak zorunda olan dolayısıyla, hem kendi organizasyonlarını hem de organizasyonlarının çevresini iyi tanıyan çalışanlardır. Mali politikaların geliştirilmesi, yeni hizmet/ürün için çevre araştırması gibi işlemler stratejik düzeyde yer alan yöneticiler tarafından gerçekleştirilir (Anameriç, 2005b: 31). Bilgi profesyonelleri ayrıca tüm organizasyonu kontrol ve denetlemekten sorumludur. Hedefler, stratejik planlar ve işletme politikaları doğrultusunda iş rutinini geliştirmek üzere kaynakları harekete geçirmede önemli bir rol oynamaktadırlar. Buna ek olarak bilgi profesyonelleri hissedarlara ve kamuoyuna karşı sorumlu olan kişilerdir. (Boundless, 2015: 1). Geleneksel muhasebe bilgi sistemi stratejik düzeyde bilgi profesyonellerinin kullanımı için yeterli ve esnek bir altyapıya sahip değildir. Operasyonel ve en fazla taktiksel düzey için formal ve standart bir altyapı sunmaktadır. Bu nedenle büyük ölçüde belirsizlik içeren stratejik kararların alınmasında yetersiz kalmaktadır. Kurumsal bilgelik anlayışının formal yapıların 
dışında bir iletişimi ve bilgi transferini hedeflemesi, demokratik kültürü, ve dönüşümcü liderliği benimsemesi muhasebenin bilgi profesyonellerinin kararlarına daha çok katk1 yapmasına imkan sağlamaktadır.

\subsection{Muhasebe Bilgi Sisteminde Bilgi Üretimi}

Muhasebe bilgi sisteminin ürettiği nitelikli bilgiler ile işletme faaliyetlerinin verimliliğinin ve karlılığının artması hedeflenir. Üretilen bilgilerin, işletmenin yasal olarak yerine getirmesi gereken yükümlülüklerin büyük bir kısmını da karşılaması öngörülür. Esasen muhasebe bilgi sistemi, yasal yükümlülükleri ve geleneksel anlayışı nedeniyle formal bilgilere dayalı bilgi üretimi ve standart raporlama yapan bir bilgi sistemi olarak kabul edilmiştir. Değişen şartlar ve bilgi gereksinimlerinin farklılaşması ile muhasebe bilgi sisteminin yönetime ve işletme süreçlerine daha fazla katkı yapması istenmektedir. $\mathrm{Bu}$ doğrultuda muhasebenin finansal muhasebe ile büründügü formal yapının dışında informal bir yapıya da açık olması gerekir. Informal yapı ile elde edilen bilgilerin farklılaşmasına sebep olacağı gibi geri bildirim ve raporların niteliğini de arttıracağı beklenir.

Kurumsal bilgelik anlayışı ile muhasebe bilgi sisteminin yönetim muhasebesi kapsamında verimli geri bildirimler ve raporlar hazırlaması, üretilecek nitel bilgiye bağlıdır. Bu doğrultuda işletme faaliyetleriyle ilgili formal ve informal bilgiye dayalı geri bildirimlerin elde edilmesi gerekmektedir. Yönetim muhasebesinde geleneksel olarak geri bildirimler, formal kontrol döngüsünde kurum karnesi (balanced scoreard) gibi amaçlar ve performans ölçümlerinin formal bilgi sistemi ile matematiksel görünümüdür. Halbuki geri bildirimlerin ortak yönetim hedefleri doğrultusunda hem formal hem de informal süreçlerden etkilenen daha geniş kapsama sahip olması gerekir (Pitkanen ve Lukka, 2010:1). Çoğu modern organizasyonların ve geliştirilmiş bilgi sistemine sahip işletmelerin karşı karşıya kaldığı önemli bir paradoks hala yeterli ve sürekli çalışan geri bildirimlerinin alınamamasıdır. İşletmenin örtük bilgisi olarak kabul edilen bu tarz bilgiler, günümüzde raporların niteliğini arttırıcı bir unsur olarak görülmektedir. İnformal bilgi üretimi ile bağdaşan kurum içi örtük bilginin açığa çıkartılması ve kullanılması gerekmektedir

Kurumsal bilgelik, kurumsal problemlerin pratik çözümü için gerekli olan bilginin kullanımıdır. Sahip olunan tüm açık ve örtük bilginin etkin biçimde yönetilmesi ile kurumsal bilgeliğe ulaşılmaktadır (Bierly vd., 2000: 603). Bilgi yönetim süreci sonucunda elde edilen bilgi, tek başına kopyalanabilen ve taklit edilebilen bir unsurdur. Ancak bilgi, kurumsal bilgelik bağlamında ele alınarak kurumun deneyim, zekâ, duygu, öğrenme, sistematik düşünme, değerler, esaslar, varsayımlar ile birleşip tehdit ve firsatlarda kullanıldığında taklit edilmesi neredeyse imkânsız hale gelmektedir (Kaygısız ve Çağlıyan, 2014: 238). Bu yüzden kurumsal bilgeliğin oluşturulması için bilgi yönetimi uygulamalarının açık ve örtük bilgiyi bir bütün olarak kabul etmesi ve çalışanlar başta olmak üzere iç ve dış paydaşları da birer bilgi kaynağı olarak görmesi gerekmektedir.

Muhasebe bilgi sisteminin informal bilgi kaynaklarına ulaşmakla kalmayıp bu bilgileri ihtiyaçlar ve talepler doğrultusunda raporlarına dahil edebilmesi gerekmektedir. Genellikle formal olma zorunluluğu olan finansal muhasebe temelli raporlarda böyle bir uygulama yapmak mümkün olmayacağından, informal bilgiler ancak yönetim muhasebesi kapsamında kullanılabilir ve raporlamalara alınabilir. Genel bir değerlendirme 1şı̆̆ında muhasebe bilgi sisteminin informal bilgiye dayalı yönetim raporlarının nitelikleri şu şekilde sıralanabilir. 
- $\quad$ Kullaniclya veya Birime Özel Raporlama: Muhasebe bilgi sistemi teknolojik altyapıs1 ile standart dışı ve kullanıcıya özel rapor oluşturmaya izin verebilmelidir. Bu özellik ile bilgi kullanıcıları gereksinimlerine göre kendi raporlarını kendileri oluşturabilir. Aynı anlayışla muhasebe bilgilerinin birimlere verilen izinler çerçevesinde, ihtiyaç ve talepleri doğrultusuna istedikleri raporları oluşturabilmelerine imkan verilebilir.

- Kurumsal Zeka Destekli Raporlama: Muhasebe bilgi sistemine entegre edilen kurumsal zeka teknolojileri ile elde edilen veri ve enformasyonlar analitik incelemelere tabi tutularak nitelikli bilgi haline getirilebilir. Böylece tahmin, gelecek projeksiyonu, hata tespiti, denetim, yatırım analizi, fizibilite, vb. özellikler içeren bilgiler raporlanabilir.

- SSeffaf ve Paylaşıma Açık Raporlama: Raporlanacak bilgi, işletme gizlilik anlayışı sınırları ölçüsünde mümkün olduğunca paylaşıma açık hale getirilmelidir. İşletmenin finansal ve finansal olmayan faaliyetleri ile mali durumunun şeffaf bir şekilde paylaşılması çalışanların aidiyet duygularını arttırıcı bir etki yaratacaktır. Ayrıca genel durum ve sorunlarla ilgili farklı kesimlerden de görüşler ve çözüm önerilerine imkan sağlanmış olacaktır.

- Eşzamanlı Raporlama: Dönemsellik ilkesi gereği finansal raporlar genel itibariyle dönem sonlarını beklemek zorunda kalmaktadır. Fakat karar vericiler hızlı gelişen durumlara karşı zamansız ve dönem sonunu beklemeden bilgi talebinde bulunabilirler. Yönetime sunulacak raporlarda dönem sonunu beklemek yerine gelişen olayları analize eden anlık raporlar hazırlanabilecektir. Talep edilen raporlarda oluşabilecek tutarsızlıkları önlemek amacıyla tahminlemeler ile tamamlamalar ve düzeltmeler yapılabilecektir.

- Bütçe Karşılaştırmalı Raporlama: İşletmenin öngörülen faaliyetlerindeki sapmalar ile gerçekleşen durumlar, raporlara dahil edilmek suretiyle aksaklıklara hızlı bir şekilde müdahale edilebilecektir. Özellikle gider bütçeleri ve satış ile ilgili raporlarda uyarı mekanizmaları geliştirilebilir. Bu raporlar sayesinde bütçe karşılaştırmaları sürekli yapılarak bütçe tahminlerinin mümkün olduğunca gerçekleşmelerle tutturulması sağlanabilir.

Çalışan Katılımlı Raporlama: Raporlara çalışanların bireysel girişimleri sonucu elde ettiği bilgiler, tecrübe ve birikimleri ile yapmış oldukları tahminler, yorumlar ve sezgiler ilave edilebilir. Bu özellik karar vericilerin gözlerinden kaçırdıkları veya tahmin edemedikleri durumları fark etmelerini sağlayacaktır.

- Değerlendirmeli Raporlama: Çalışan katılımı ile gerçekleşen beyin firtınaları ve çalıştayların değerlendirmeleri de muhasebe raporları içerinde bulunmalıdır. Bu tarz raporlarda problemlere yönelik çözüm önerileri, yol haritaları ve strateji önerileri yer alabilir.

\section{MUHASEBE Bİlgi SİSTEMINDE KURUMSAL BİLGELİK ANLAYIŞI ARAŞTIRMASI}

\subsection{Araştırmanın Amacı ve Yöntemi}

Araştırmanın genel amacı, teorik olarak incelenen muhasebe bilgi sisteminde kurumsal bilgelik anlayışı konusunun pratikteki karşılığını görmek, işletmelerdeki uygulama düzeylerini belirlemek ve unsurlar arasındaki ilişkiyi ölçmektir. Bu kapsamda bir anket çalışması gerçekleştiriliştir. Anket verileriyle yapılan istatistiksel analizler, muhasebe bilgi sistemi bileşenleri ve kurumsal bilgelik kriterleri hakkında bilgi elde edilmesini sağlamıştır. Genel amaç doğrultusunda hazırlanan anket sorularının belirlenmesinde kavramsal çerçeve, teorik değerlendirmeler, ilgili literatür ve bu konuda daha önceden gerçekleştirilen benzer çalışmalardaki ölçekler dikkate alınmıştır. Ankete son şeklini vermeden önce taslak anket, konunun uzmanı akademisyenlere ve işletme yöneticilerine sunularak, görüşleri alınmıştır. 


\subsection{Hedef Kitle}

Araştırma kapsamında, Türkiye'de faaliyet gösteren, bilgi yönetiminde kurumsal bilgi yönetim yapısına ulaşmış, olgun bir muhasebe bilgi sistemi bulunan ve kurumsal kaynak planlaması sistemine sahip işletmeler hedef kitle olarak düşünülmüştür. Büyük sanayi kuruluşlarının diğer işletmelere göre daha kurumsal bir yapıda oldukları, bilgi yönetim altyapısına ve büyük bir çoğunluğunun kurumsal kaynak planlaması sistemine sahip olduğu düşünülerek, İstanbul Sanayi Odasının her yıl belirlediği ve 2015 yılında da ilan ettiği Türkiye'nin ilk 500 büyük sanayi kuruluşu hedef kitle olarak tayin edilmiştir.

\subsection{Anket Uygulaması}

Anket, hedef kitlenin iletişim numaraları üzerinden teker teker aranması, muhasebe birimi yetkililerine ulaşılması ve e-posta adresleri istenmek suretiyle, anket linkini içeren epostanın gönderilmesi ve cevap alınması yoluyla yürütülmüştür. Anketi cevaplaması için muhasebe departmanlarında çalışan şef, müdür, yönetici ve koordinatörler ilgili kişiler olarak tayin edilmiş ve işletmelerden bu kişiler talep edilmiştir. Bu doğrultuda elden edilen 324 eposta adresinden 11'i hatalı olmak üzere 313'una başarılı bir şekilde gönderilmiştir. Hedef kitlenin büyük bir çoğunluğuna birebir ulaşılmasına rağmen arzu edilen katılım sağlanamamış ankete dönüşler yüksek oranlarda olmamıştır. Sonuçta, link üzerinden cevaplanan 122 adet anket formu elde edilmiş ve yapılan değerlendirmede 106'sı geçerli sayılmıştır.

Tablo 1: Örneklem Büyüklükleri Tablosu

\begin{tabular}{|c|c|c|c|c|c|c|c|c|c|}
\hline \multirow{3}{*}{$\begin{array}{l}\text { Evren } \\
\text { Büyüklüğü }\end{array}$} & \multicolumn{3}{|c|}{${ }_{+}^{-} 0.03$ örnekleme hatası } & \multicolumn{3}{|c|}{${ }_{+}^{-0} 0.05$ örnekleme hatas 1} & \multicolumn{3}{|c|}{+0.10 örnekleme hatas1 } \\
\hline & $\mathrm{p}=0.5$ & $\mathrm{p}=0.8$ & $\mathrm{p}=0.3$ & $\mathrm{p}=0.5$ & $\mathrm{p}=0.8$ & $\mathrm{p}=0.3$ & $\mathrm{p}=0.5$ & $\mathrm{p}=0.8$ & $\mathrm{p}=0.3$ \\
\hline & $\mathrm{q}=0.5$ & $q=0.2$ & $\mathrm{q}=0.7$ & $q=0.5$ & $q=0.2$ & $\mathrm{q}=0.7$ & $q=0.5$ & $q=0.2$ & $\mathrm{q}=0.7$ \\
\hline 100 & 92 & 87 & 90 & 80 & 71 & 77 & 49 & 38 & 45 \\
\hline 500 & 341 & 289 & 321 & 217 & 165 & 196 & 81 & 55 & 70 \\
\hline
\end{tabular}

Kaynak: Yazıcı̆̆ğlu ve Erdoğan, 2004

Geçerli anket satısı toplam evren büyüklüğü içerisinde \%21,2'lik bir geri dönüş oranına tekabül etmektedir. Bu geri dönüş oranı, betimsel araştırmalarda örneklem hacminin ana kütlenin minimum \%10'u örneklem alındığ 1 için yeterli kabul edilmiştir. Yazıcıoğlu ve Erdoğan (2004) tarafından hazırlanan ve $\alpha=0.05$ için +- 0.03 , +- 0.05 ve +- 0.10 örnekleme hataları için farklı evren büyüklüklerinden çekilmesi gereken örneklem büyüklüklerinin hesaplandığ kısımları alınarak aşağıda tablo 1'de $\alpha=0.05$ (\%95 güven aralığında) ve örnekleme hatası \% 10 olduğunda ana kütle büyüklüğü 500 iken 81 olması gerektiği gösterilmiştir. Bu kapsamda kabul edilen 106 adet anket örneklemin güvenirliliği açısından yeterli görülmüştür.

\subsection{Bulgular ve Değerlendirmeler}

Anket verilerinin istatistiki analizi ve yorumları için istatistik paket programı SPSS.15 kullanılmıştır. Öncelikle ankette kullanılan ölçeklerin güvenirliği hesaplanmıştır. Bu kapsamda değerlendirmeye alınan tüm bileşen ve kriterler ile ilgili hazırlanan sorulara ilişkin veriler güvenilirlik testine tabi tutulmuştur. Hesaplanan Cronbach's Alpha Katsayısı değerlerin tamamı 0,7 değerinden fazla olduğundan bütün ölçekler güvenilir bulunmuştur. Sonuçlar tablo-2'de gösterilmektedir. 
Tablo 2: Bileşen ve Kriter Soruları Güvenilirlik Değerleri

\begin{tabular}{lcc}
\hline & $\mathrm{N}$ & Cronbach's Alpha \\
\hline Bilgi Çalışanları & 3 & 0,766 \\
\hline Bilgi Kaynakları & 4 & 0,841 \\
\hline Bilgi Teknolojileri & 3 & 0,822 \\
\hline Bilgi Üretimi & 6 & 0,874 \\
\hline Dönüşümcü Liderlik & 3 & 0,750 \\
\hline Kurumsal Demokrasi & 3 & 0,831 \\
\hline Kurum Kültürü ve Altyapısı & 3 & 0,848 \\
\hline Kurumsal Yenilikçilik ve Değişim & 3 & 0,822 \\
\hline Öğrenen örgüt ve Örgütsel Öğrenme & 3 & 0,891 \\
\hline Bilgi Transferi & 3 & 0,899 \\
\hline \multicolumn{1}{c}{ Kurumsal Sürdürülebilirlik } & & 0,882 \\
\hline
\end{tabular}

Araştırmaya katılan işletmelerin hukuki yapıları ve faaliyet konularına göre bulundukları sektörler sorgulanmış ve genel bilgileri elde edilmiştir. Tablo 3'deki bilgilere göre \%87'si anonim şirket olan hedef kitlenin, sanayi kuruluşları seçilmesiyle orantılı olarak, \%89’luk kısmının üretim yaptıkları öğrenilmiştir.

Tablo 3: Hedef Kitle Genel Bilgiler

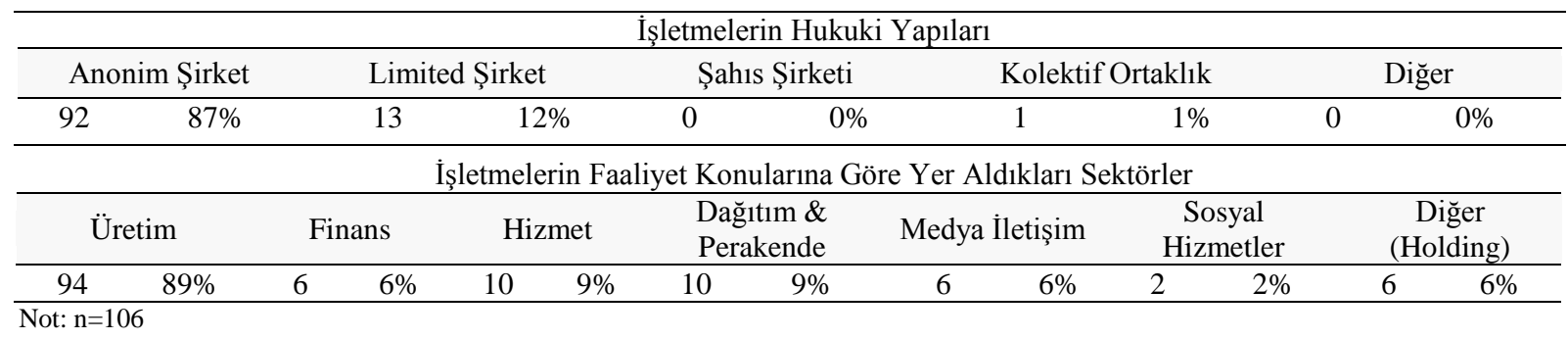

Ankete katılan işletmelerde anketi cevaplayan yetkili kişilerin bilgi çalışanları sınıflandırmasına göre dağılımı ve işletmeler bünyesindeki bilgi çalışanları sayıları tablo4'deki gibi belirlenmiştir.

Tablo 4: Anketi Cevaplayan Bilgi Çalışanlarının Dağglımı

\begin{tabular}{cccccc}
\hline \multicolumn{2}{c}{ Bilgi İşcisi } & \multicolumn{2}{c}{ Bilgi Yöneticisi } & \multicolumn{2}{c}{ Bilgi Profesyoneli } \\
\hline 16 & $15 \%$ & 46 & $43 \%$ & 44 & $42 \%$ \\
\hline Not: $\mathrm{n}=106$ & & & &
\end{tabular}

Tablo 5: Bilgi Çalışanlarının Analizi

\begin{tabular}{lccccccc}
\hline & Toplam & Ortalama/Dă̆lım & Std.Sapma & Varyans & Max. & Min \\
\hline Bilgi İşçisi & 10.914 & 102,96 & $66 \%$ & 408 & 166.603 & 2.500 & 4 \\
\hline Bilgi Yöneticisi & 4.706 & 44,40 & $28 \%$ & 280 & 78.394 & 1.784 & 2 \\
\hline Bilgi Profesyoneli & 930 & 8,77 & $6 \%$ & 31 & 985 & 200 & 1 \\
\hline Not: $n=106$ & & & & & &
\end{tabular}

Tablo 5'de yapılan analize göre ortalama bir şirkette 156,13 bilgi çalışanı yer almakta olup, bu çalışanların \% 66'sı bilgi işçilerinden \% 28'si bilgi yöneticilerinden \% 6'sı ise bilgi profesyonellerinden oluşmaktadır. 
Tablo 6: Kurumsal Bilgi Yönetimini Oluşturan Sermayelerin Analizi

\begin{tabular}{|c|c|c|c|c|c|c|c|c|}
\hline \multirow[b]{2}{*}{$\begin{array}{l}\text { Entelektüel Sermaye }=\text { Sosyal Sermaye+Yapısal } \\
\text { Sermaye+İnsan Sermayesi }\end{array}$} & \multicolumn{2}{|c|}{ Toplam } & \multicolumn{2}{|c|}{$\begin{array}{l}\text { Ortalama } \\
\text { /Dağılım }\end{array}$} & \multirow{2}{*}{$\begin{array}{c}\begin{array}{c}\text { Std. } \\
\text { Sapma }\end{array} \\
1,23\end{array}$} & \multirow{2}{*}{$\begin{array}{c}\text { Varyans } \\
1,51\end{array}$} & \multirow{2}{*}{$\frac{\text { Max }}{5}$} & \multirow{2}{*}{$\frac{\text { Min }}{1}$} \\
\hline & 354 & $67 \%$ & 3,34 & $25 \%$ & & & & \\
\hline $\begin{array}{l}\text { İnsan Sermayesi, } \\
\text { (Bireysel beceri, deneyim ve yeterlilikler) }\end{array}$ & 368 & $69 \%$ & 3,47 & $26 \%$ & 0,92 & 0,85 & 5 & 1 \\
\hline $\begin{array}{l}\begin{array}{l}\text { Sosyal Sermaye } \\
\text { (İşletme dıșı ve içi ile ilişkiler ve işbirlikleri) }\end{array} \\
\end{array}$ & 318 & $60 \%$ & 3 & $23 \%$ & 1,08 & 1,17 & 5 & 1 \\
\hline $\begin{array}{l}\text { Yapısal Sermaye } \\
\text { (Alt yapılar, süreçler, sistemler, kurum kültürü) }\end{array}$ & 366 & $69 \%$ & 3,45 & $26 \%$ & 1,06 & 1,12 & 5 & 1 \\
\hline
\end{tabular}

Not: n=106, Puanlama= (5) En Büyük, (1)En Küçük

Bilgi yönetiminin sermaye büyüklüklerinin istenildiği soruda işletmelerden en büyük 5 en küçük 1 olmak üzere sermayelerini değerlendirmeleri istenmiştir. Verilen yanıtlara göre sermaye büyüklüklerinin birbirine yakın olduğu en düşük sermaye büyüklüğünün işletme bünyesinde $\% 60$, diğer sermayeler arasında \% 23' lük ortalama ile sosyal sermaye, en büyük sermayenin işletme içinde \% 69 ve diğerleri arasında \% 26 ile insan ve yapısal sermayeler olduğu görülmüştür. (Tablo 6).

Tablo 7: Bilgi Teknolojileri Analizi

\begin{tabular}{|c|c|c|c|c|c|c|c|c|}
\hline \multirow[b]{2}{*}{$\begin{array}{l}\text { Uzman Sistemler } \\
\text { (Stratejik düzey bilgi teknolojileri) }\end{array}$} & \multicolumn{2}{|c|}{ Toplam } & \multicolumn{2}{|c|}{$\begin{array}{l}\text { Ortalama } \\
\text { /Dağılım }\end{array}$} & \multirow{2}{*}{$\begin{array}{c}\begin{array}{c}\text { Std. } \\
\text { Sapma }\end{array} \\
1,22\end{array}$} & \multirow{2}{*}{$\begin{array}{c}\text { Varyans } \\
1,49\end{array}$} & \multirow{2}{*}{$\frac{\text { Max }}{5}$} & \multirow{2}{*}{$\frac{\text { Min }}{1}$} \\
\hline & 364 & $69 \%$ & 3,43 & $35 \%$ & & & & \\
\hline $\begin{array}{l}\text { Karar Destek Sistemleri } \\
\text { (Taktiksel düzey bilgi teknolojileri) }\end{array}$ & 354 & $67 \%$ & 3,34 & $34 \%$ & 1,06 & 1,13 & 5 & 1 \\
\hline $\begin{array}{l}\text { Kurumsal Zeka Teknikleri } \\
\text { (Operasyonel düzey bilgi teknolojileri) }\end{array}$ & 326 & $62 \%$ & 3,08 & $31 \%$ & 1,13 & 1,28 & 5 & 1 \\
\hline
\end{tabular}

Not: $\mathrm{n}=106$, Puanlama= (5) Çok Yaygın Kullanım, (1)Kullanım Yok

Bilgi teknolojileri kullanım sıklıklarına ilişkin sorulan soruya verilen yanıtlara göre işletmeler, kurumsal zeka teknolojileri içerisinde \% 69 kullanım ile en çok stratejik düzeyde görülen uzman sistemleri, \% 62 kullanım ile en az operasyonel düzeyde kullanılan kurumsal zeka teknolojilerini kullanmaktadırlar. (Tablo 7).

Bilgi üretimi bileşeni için 6 farklı soru ile işletmenin stratejik, taktiksel ve operasyonel düzey faaliyetleri sorgulanmıştır. Tablo 8'de yapılan analize göre işletmelerin \%79'luk oranla en çok zorunlu olarak düzenledikleri raporların dışında, karar alma süreçlerine katkı yapan nitelikli bilgi üretimi yaptıkları, \%70'lık oranla da en az bilgi çalışanlarının örtük bilgilerini açığa çıkaracak ortam ve yapılanmalara sahip oldukları öğrenilmiştir. Kurumsal bilgelik anlayışında bilgi üretimi için sıralama yapıldığı takdirde stratejik düzeyde en çok, operasyonel düzeyde en az bilgi üretimi gerçekleştirildiği görülmektedir.

Tablo 8: Bilgi Üretimi Analiz Tablosu

\begin{tabular}{|c|c|c|c|c|c|c|c|c|}
\hline \multirow[b]{2}{*}{ Nitelikli Bilgi Üretimi } & \multicolumn{2}{|c|}{ Toplam } & \multicolumn{2}{|c|}{$\begin{array}{l}\text { Ortalama } \\
\text { /Dağılım }\end{array}$} & \multirow{2}{*}{$\begin{array}{c}\begin{array}{c}\text { Std. } \\
\text { Sapma }\end{array} \\
1,57\end{array}$} & \multirow{2}{*}{$\frac{\text { Varyans }}{1,33}$} & \multirow{2}{*}{$\frac{\text { Max }}{5}$} & \multirow{2}{*}{$\frac{\text { Min }}{1}$} \\
\hline & 418 & $79 \%$ & 3,94 & $18 \%$ & & & & \\
\hline Kullanıcıya ve Birime Özel Raporlama & 408 & $77 \%$ & 3,85 & $17 \%$ & 1,11 & 1,22 & 5 & 1 \\
\hline Formal Geri Bildirimler & 386 & $73 \%$ & 3,64 & $16 \%$ & 1,13 & 1,29 & 5 & 1 \\
\hline İnformal Geri Bildirimler & 380 & $72 \%$ & 3,56 & $16 \%$ & 1,05 & 1,11 & 5 & 1 \\
\hline Örtük Bilgiyi Açığa Çıkarma & 372 & $70 \%$ & 3,85 & $16 \%$ & 1,11 & 1,23 & 5 & 1 \\
\hline Şeffaf ve Paylaşıma Açık Raporlama & 380 & $72 \%$ & 3,56 & $16 \%$ & 1,25 & 1,56 & 5 & 1 \\
\hline
\end{tabular}

Not: n=106, Puanlama= (5) \%100 Uygulama Var, (1)Uygulama Yok 
Anket çalışmasında kurumsal bilgelik anlayışının tüm kriterleri değerlendirmeye alınmıştır. Her kriter için ayrı ayrı likert ölçekli hazırlanan sorulara verilen yanıtlar analiz edilmiş, frekans ortalamaları ve istatistiki değerleri elde edilmiştir. Her kriter sorusu için üçer tane alt soru hazırlanmış böylece o kritere ilişkin sırasıyla stratejik, taktiksel ve operasyonel bilgi düzeylerinin değerlendirmesi yapılmıştır.

Tablo 9: Dönüşümcü Liderlik Kriter Değerlendirmesi Analizi

\begin{tabular}{|c|c|c|c|c|c|c|c|c|}
\hline \multirow[b]{2}{*}{ Astların Motivasyonu ve Antrenörlük } & \multicolumn{2}{|c|}{ Toplam } & \multicolumn{2}{|c|}{$\begin{array}{l}\text { Ortalama } \\
\text { /Dağılım }\end{array}$} & \multirow{2}{*}{$\begin{array}{c}\begin{array}{c}\text { Std. } \\
\text { Sapma }\end{array} \\
1,13 \\
\end{array}$} & \multirow{2}{*}{$\begin{array}{c}\text { Varyans } \\
1,28 \\
\end{array}$} & \multirow{2}{*}{$\begin{array}{c}\text { Max } \\
5 \\
\end{array}$} & \multirow{2}{*}{$\begin{array}{r}\text { Mir } \\
1 \\
\end{array}$} \\
\hline & 354 & $67 \%$ & 3,34 & $31 \%$ & & & & \\
\hline $\begin{array}{l}\text { Farklı Yaklaşım ve Çalışan Görüşlerinin Dikkate } \\
\text { Alınması }\end{array}$ & 402 & $76 \%$ & 3,79 & $35 \%$ & 1,03 & 1,07 & 5 & 1 \\
\hline Karar Verme ve Risk Almanın Cesaretlendirilmesi & 380 & $72 \%$ & 3,58 & $33 \%$ & 1,02 & 1,04 & 5 & 1 \\
\hline
\end{tabular}

Tablo 9'a göre işletmeler dönüşümcü liderlik uygulamalarında stratejik düzey için \% 67, taktiksel düzey için \% 76 ve operasyonel düzey için \% 72 oranlarda bulunduklarını belirtmişlerdir. Bu doğrultuda üst yöneticiler motivasyon ve antrenörlük faaliyetlerinde düşük performans göstermektedirler. Taktiksel düzeyde farklı yaklaşım ve görüşler için ortam ve koşullar sağlanmıştır. Muhasebe faaliyetlerinde bilgi işçilerinin işletme menfaatleri doğrultusunda ve yetkileri ölçüsünde karar vermeleri ve risk almaları yeterli düzeyde cesaretlendirilmektedir.

Tablo 10: Kurumsal Demokrasi Kriter Değerlendirmesi Analizi

\begin{tabular}{|c|c|c|c|c|c|c|c|c|}
\hline \multirow[b]{2}{*}{$\begin{array}{l}\text { Demokratik Kültürün Kritik Başarı Faktörü Olarak } \\
\text { Görülmesi }\end{array}$} & \multicolumn{2}{|c|}{ Toplam } & \multicolumn{2}{|c|}{$\begin{array}{l}\text { Ortalama } \\
\text { /Dağılım }\end{array}$} & \multirow{2}{*}{$\begin{array}{c}\begin{array}{c}\text { Std. } \\
\text { Sapma }\end{array} \\
1,11\end{array}$} & \multirow{2}{*}{$\frac{\text { Varyans }}{1,23}$} & \multirow{2}{*}{$\frac{\text { Max }}{5}$} & \multirow{2}{*}{$\frac{\text { Min }}{1}$} \\
\hline & 378 & $71 \%$ & 3,57 & $34 \%$ & & & & \\
\hline Yetki Devri Faaliyetleri, Terfi ve Ödül Sistemi & 344 & $65 \%$ & 3,25 & $31 \%$ & 1,06 & 1,13 & 5 & 1 \\
\hline Eşit Katılım İle Görüş Belirtme, Sorunların Tartışılması & 378 & $71 \%$ & 3,57 & $34 \%$ & 1,12 & 1,26 & 5 & 1 \\
\hline
\end{tabular}

Kurumsal demokrasi uygulamasında bilgi yönetim düzeyleri için sırasıyla \% 71, \% 65 ve $\% 71$ oranlarında uygulamalar görülmektedir. (Tablo 10). İşletmelerde taktiksel düzeyde daha az katılımla yetki devri, terfi ve ödül sistemleri ile çalışanların bilgi üretimine katılımı canlı tutulmaya çalış1lırken, stratejik düzeyde demokratik kültür daha çok kritik başarı faktörü olarak görülmekte, operasyonel düzey muhasebe bilgi çalışanlarının eşit katılım hakkıyla görüşlerini rahatlıkla söylemeleri ve sorunları tartışarak bilgi yönetim sürecine katkı yapmaları istenmektedir.

Tablo 11: Kurum Kültürü ve Yapısı Kriter Değerlendirmesi Analizi

\begin{tabular}{|c|c|c|c|c|c|c|c|c|}
\hline \multirow[b]{2}{*}{ Bilgi Yönetiminde Özendirici Ortam ve Unsurlar } & \multicolumn{2}{|c|}{ Toplam } & \multicolumn{2}{|c|}{$\begin{array}{l}\text { Ortalama } \\
\text { /Dağıllım }\end{array}$} & \multirow{2}{*}{$\begin{array}{c}\begin{array}{c}\text { Std. } \\
\text { Sapma }\end{array} \\
1,21\end{array}$} & \multirow{2}{*}{$\frac{\text { Varyans }}{1,45}$} & \multirow{2}{*}{$\frac{\text { Max }}{5}$} & \multirow{2}{*}{$\frac{\text { Min }}{1}$} \\
\hline & 378 & $71 \%$ & 3,57 & $31 \%$ & & & & \\
\hline Değer, İnanç ve Normlara Uygunluk & 380 & $72 \%$ & 3,85 & $31 \%$ & 1,11 & 1,22 & 5 & 1 \\
\hline Muhasebe İlkeleri ve Meslek Etiğine Uyum & 462 & $87 \%$ & 4,36 & $38 \%$ & 0,95 & 0,91 & 5 & 1 \\
\hline
\end{tabular}

Kurum kültürü ve yapısı kriteri için yukarıdan aşağıya doğru bilgi yönetim düzeylerine göre $\% 71, \% 72$ ve \% 87 oranlarında uygulamalar bulunmaktadır. (Tablo 11). İşletmelerin 
operasyonel düzeyde muhasebe ilkeleri ve meslek etiğine uyumu göze çarpmaktadır. Diğer yandan yeterli seviyede bilgiyi elde etmek, geliştirmek, paylaşmak için özendirici ortam ve unsurlar oluşturulmuş, muhasebe bilgi sistemi bu altyapıda odak fonksiyon olarak yer almakta, kurumun değer, inanç ve normlarına uygun olarak katkı yapmaktadır.

Tablo 12: Kurumsal Yenilikçilik ve Değişim Kriter Değerlendirmesi Analizi

\begin{tabular}{|c|c|c|c|c|c|c|c|c|}
\hline \multirow[b]{2}{*}{$\begin{array}{l}\text { Yeniliklere ve Değişikliklere Duyarlı Organizasyon } \\
\text { Yapısı }\end{array}$} & \multicolumn{2}{|c|}{ Toplam } & \multicolumn{2}{|c|}{$\begin{array}{l}\text { Ortalama } \\
\text { /Dağılım }\end{array}$} & \multirow{2}{*}{$\begin{array}{c}\begin{array}{c}\text { Std. } \\
\text { Sapma }\end{array} \\
1,13\end{array}$} & \multirow{2}{*}{$\begin{array}{c}\text { Varyans } \\
1,27\end{array}$} & \multirow{2}{*}{$\frac{\text { Max }}{5}$} & \multirow{2}{*}{$\frac{\text { Min }}{1}$} \\
\hline & 390 & $74 \%$ & 3,68 & $35 \%$ & & & & \\
\hline $\begin{array}{l}\text { Bilgi, Teknoloji, Patent, Know-How vb. Yenilik ve } \\
\text { Değișimlerinin İzlenmesi }\end{array}$ & 350 & $66 \%$ & 3,30 & $31 \%$ & 1,21 & 1,46 & 5 & 1 \\
\hline $\begin{array}{l}\text { Kurum Dışı Faaliyetleri Katılım İle Gelişmelerin } \\
\text { Takibi }\end{array}$ & 380 & $72 \%$ & 3,58 & $34 \%$ & 1,24 & 1,53 & 5 & 1 \\
\hline
\end{tabular}

Not: n=106, Puanlama= (5) \%100 Uygulama Var, (1)Uygulama Yok

Tablo 12'de gösterilen analize göre, işletmeler stratejik kararlar doğrultusunda \% 74'lük oranla yeni yapılanmalara ve iş süreçlerine, değişen politikaları duyarlı olduklarını belirtirken, bilgi, teknoloji, patent, know-how gibi taktiksel düzey yenilik ve değişimlerde \% 66'lık performans gösterebildiklerini bildirmişlerdir. Operasyonel düzey muhasebe çalışanlarının mevzuat ve uygulamalardaki gelişmeleri takip etmek üzere kurum dışı çalıştay, toplantı, seminer vb. katılımı \% 72 oranında gerçekleşmektedir.

Tablo 13: Öğrenen Örgüt ve Örgütsel Öğrenme Kriter Değerlendirmesi Analizi

\begin{tabular}{|c|c|c|c|c|c|c|c|c|}
\hline \multirow[b]{2}{*}{ Sürekli ve Bireysel Öğrenmenin Teşvik Edilmesi } & \multicolumn{2}{|c|}{ Toplam } & \multicolumn{2}{|c|}{$\begin{array}{l}\text { Ortalama } \\
\text { /Dağ1lım }\end{array}$} & \multirow{2}{*}{$\begin{array}{c}\begin{array}{c}\text { Std. } \\
\text { Sapma }\end{array} \\
1,04 \\
\end{array}$} & \multirow{2}{*}{$\begin{array}{c}\text { Varyans } \\
1,08 \\
\end{array}$} & \multirow{2}{*}{$\frac{\operatorname{Max}}{5}$} & \multirow{2}{*}{$\begin{array}{c}\text { Min } \\
1\end{array}$} \\
\hline & 366 & $69 \%$ & 3,45 & $34 \%$ & & & & \\
\hline $\begin{array}{l}\text { Beyin Furtınaları İle İnformal Bilgi Edinimi ve Formal } \\
\text { Bilgilerle Harmanlanması }\end{array}$ & 348 & $66 \%$ & 3,28 & $32 \%$ & 1,03 & 1,07 & 5 & 1 \\
\hline $\begin{array}{l}\text { Öğrenerek Kazanılan Bilgilerin Görüş ve Yorum } \\
\text { Olarak Raporlarda Kullanılması }\end{array}$ & 358 & $68 \%$ & 3,38 & $33 \%$ & 1,17 & 1,37 & 5 & 1 \\
\hline
\end{tabular}

Not: n=106, Puanlama= (5) \%100 Uygulama Var, (1)Uygulama Yok

Öğrenen örgüt ve örgütsel öğrenme kriteri bağlamında işletmelerin tüm düzeylerde birbirine yakın ortalamalarla uygulamalara sahip oldukları tablo 13'de belirtildiği gibi tespit edilmiştir. İşletmeler \% 69'luk bir oranla kurumsal zekânın arttırılması için, sürekli ve bireysel öğrenmenin teşvik edildiği bir anlayış muhasebe birimi genelinde yaygınlaştırmakta çalışanların kurum içinden veya dışından eğitim almaları sağlanmaktadır. Diğer yandan \% 66'lık bir oranla taktiksel anlamda beyin firtınaları ile informal bilgiler elde etmeye de çalışmakta, formal bilgiler ile harmanlayarak karar süreçlerine destek olarak kullanmaktadırlar. Operasyonel düzeyde ise bilgi işçilerinin öğrenerek kazandığı bilgiler, görüş ve yorumlar muhasebe raporlarına \% 68'lik bir oranlar ilave edilmektedir.

Tablo 14: Bilgi Transferi Kriter Değerlendirmesi Analizi

\begin{tabular}{|c|c|c|c|c|c|c|c|c|}
\hline \multirow[b]{2}{*}{$\begin{array}{l}\text { Dış Kaynaklı Bilgiler İle İnformal İletişime Dayalı } \\
\text { Bilgilerin Kullanılması }\end{array}$} & \multicolumn{2}{|c|}{ Toplam } & \multicolumn{2}{|c|}{$\begin{array}{l}\text { Ortalama } \\
\text { /Dağılım }\end{array}$} & \multirow{2}{*}{$\begin{array}{c}\begin{array}{c}\text { Std. } \\
\text { Sapma }\end{array} \\
1,24\end{array}$} & \multirow{2}{*}{$\begin{array}{c}\text { Varyans } \\
1,67\end{array}$} & \multirow{2}{*}{$\frac{\text { Max }}{5}$} & \multirow{2}{*}{$\frac{\text { Min }}{1}$} \\
\hline & 340 & $64 \%$ & 3,21 & $31 \%$ & & & & \\
\hline Bilgilerin Özellik, Sınırlılık ve İlgililerinin Belirlenmesi & 382 & $72 \%$ & 3,60 & $35 \%$ & 1,17 & 1,37 & 5 & 1 \\
\hline Bilgi Transfer Standartları, Standartlara Adaptasyon & 382 & $72 \%$ & 3,60 & $35 \%$ & 1,12 & 1,26 & 5 & 1 \\
\hline
\end{tabular}


İşletmeler \% 72'lik oranlarla muhasebe bilgi sisteminde hangi bilgilerin, hangi özelliklerde ve sınırlılıklarda, hangi düzeydeki ilgililere transfer edileceği belirlemiş ve etkin bilgi transferi ve gösterimini sağlamak için oluşturulan standartlara bilgi çalışanlarının adaptasyonu sağlanmıştır. \% 64'lük daha az bir oranla dış kaynaklı bilgiler ile informal iletişime dayalı bilgileri kullanmaya yönelik çalışmalar yürütülmektedir. (Tablo 14).

Tablo 15: Kurumsal Sürdürülebilirlik Kriter Değerlendirmesi Analizi

\begin{tabular}{|c|c|c|c|c|c|c|c|c|}
\hline \multirow[b]{2}{*}{ Sürdürülebilirlik Planlamasından Aktif Rol Oynama } & \multicolumn{2}{|c|}{ Toplam } & \multicolumn{2}{|c|}{$\begin{array}{l}\text { Ortalama } \\
\text { /Dağılım }\end{array}$} & \multirow{2}{*}{$\begin{array}{c}\begin{array}{c}\text { Std. } \\
\text { Sapma }\end{array} \\
1,18\end{array}$} & \multirow{2}{*}{$\frac{\text { Varyans }}{1,38}$} & \multirow{2}{*}{$\frac{\operatorname{Max}}{5}$} & \multirow{2}{*}{$\frac{\text { Min }}{1}$} \\
\hline & 370 & $70 \%$ & 3,49 & $31 \%$ & & & & \\
\hline $\begin{array}{l}\text { Sürdürülebilirlik Raporlamaları İçin Altyapı, Bilgi ve } \\
\text { Tecrübe Yeterliliği }\end{array}$ & 412 & $78 \%$ & 3,89 & $34 \%$ & 1,09 & 1,19 & 5 & 1 \\
\hline Sosyal Sorumluluk Ve Meslek Etiğinin Benimsenmesi & 418 & $79 \%$ & 3,94 & $35 \%$ & 1,00 & 1,00 & 5 & 1 \\
\hline
\end{tabular}

Kurumsal sürdürülebilirlik kriteri için Tablo 15 yapılan analizi göstermektedir. Muhasebe birimi işletmelerin vizyon ve misyonuna uygun sürdürülebilirlik planlamalarında $\% 70$ oranında rol oynarken, $\% 78$ oranında sürdürülebilirlik raporlamaları ve standartları kapsamında yeterli alt yapı, bilgi ve tecrübeye sahiptir. Ayrıca operasyonel bilgi çalışanları tarafından sosyal sorumluluk ve meslek etiği konuları \% 79'luk bir oranla benimsenmiştir.

Anket verileriyle bileşenler olarak kabul edilen bilgi çalışanları, bilgi kaynakları, bilgi teknolojileri ve bilgi üretimi ölçekleri ile kriterler olarak kabul edilen dönüşümcü liderlik, kurumsal demokrasi, kurum kültürü ve yapısı, kurumsal yenilikçilik ve değişim, öğrenen örgüt ve örgütsel öğrenme, bilgi transferi ve kurumsal sürdürülebilirlik ölçekleri arasındaki ilişki hesaplanmıştır. Bu hesaplama için Pearson korelasyon analizi ile ilişki katsayıları bulunmuştur.

Tablo 16: Bileşen ve Kriter Korelasyon Tablosu

\begin{tabular}{lcccccccc}
\hline & \multicolumn{2}{c}{ Bilgi Çalışanları } & \multicolumn{2}{c}{ Bilgi Kaynaklar1 } & \multicolumn{2}{c}{ Bilgi Teknolojileri } & \multicolumn{2}{c}{ Bilgi Üretimi } \\
\hline & $\begin{array}{c}\text { Pearson } \\
\text { Corr. }\end{array}$ & $\begin{array}{c}\text { Sig.(2- } \\
\text { tailed) }\end{array}$ & $\begin{array}{c}\text { Pearson } \\
\text { Corr. }\end{array}$ & $\begin{array}{c}\text { Sig.(2- } \\
\text { tailed) }\end{array}$ & $\begin{array}{c}\text { Pearson } \\
\text { Corr. }\end{array}$ & $\begin{array}{c}\text { Sig.(2- } \\
\text { tailed) }\end{array}$ & $\begin{array}{c}\text { Pearson } \\
\text { Corr. }\end{array}$ & $\begin{array}{c}\text { Sig.(2- } \\
\text { tailed) }\end{array}$ \\
\hline Dönüşümcü Liderlik &, 751 & 0 &, 599 & 0 &, 449 & 0 &, 589 & 0 \\
\hline Kurumsal Demokrasi &, 719 & 0 &, 687 & 0 &, 668 & 0 &, 650 & 0 \\
\hline Kurum Kültürü ve Altyapis1 &, 661 & 0 &, 617 & 0 &, 535 & 0 &, 567 & 0 \\
\hline Kurumsal Yenilikçilik ve Değişim &, 596 & 0 &, 631 & 0 &, 500 & 0 &, 645 & 0 \\
\hline Öğrenen örgüt ve Örgütsel Öğrenme &, 723 & 0 &, 545 & 0 &, 508 & 0 &, 568 & 0 \\
\hline Bilgi Transferi &, 611 & 0 &, 596 & 0 &, 546 & 0 &, 625 & 0 \\
\hline Kurumsal Sürdürülebilirlik &, 603 & 0 &, 552 & 0 &, 388 & 0 &, 519 & 0 \\
\hline Not: $\mathrm{n}=106$ & & & & & & & &
\end{tabular}

Tablo 16'da yapılan analize göre bileşenler ile kriterler arasında farklı oranlarda pozitif yönde ve genel olarak ( $\mathrm{P}$ değeri $=0,000<0,05)$ orta seviyede bir ilişkilerin mevcut olduğu görülmüştür. Bileşenlerin tüm kriterlerdeki ilişki puanlarının ortalamaları alındığında bilgi çalışanları \%66,6 bilgi kaynakları \%60,4 bilgi teknolojileri \%51,3 ve bilgi üretimi \%59,6 oranlarına sahip olmaktadırlar. Buna göre bilgi çalışanları bileşeni tüm kriterler ile diğer bileșenlere göre yüksek derecede ilişki içerisinde bulunmaktadır. Bilgi kaynakları ve bilgi üretimi bileşenlerinin de tüm bileşenlerle ortanın üstü oranlarla ilişkili de olduğu görülmektedir. Bilgi teknolojileri bileşeninin, kurumsal bilgelik kriterleri ile nispeten daha zayıf ilişki de olduğu söylenebilir. 


\section{SONUÇ}

İnsana has bir kavram olan bilgeliğin, kurumsal boyutta şekillendiği, kurumun bilge olma durumunu ifade eden ve kurumsal aklı kullanmayı öngören kurumsal bilgelik, günümüzde bilgi yönetimine yeni bir soluk kazandırmaktadır. Optimum bilgi yönetiminin olarak da ifade edilen kurumsal bilgelik anlayışı, işletme stratejilerinde önemli rol oynayan muhasebe fonksiyonunu ve bilgi sistemini geliştirecek şekilde ele alınabilir. Bu öngörü, bu çalışmanın çıkış noktası olmuştur. Muhasebe bilgi sisteminin bilgi yönetimi bağlamındaki bileşenlerini inceleyen, kurumsal bilgelik anlayışının kriterleri ile ilişkilerini açıklayan, çalışma bir çok soyut kavram üzerinde teorik bir değerlendirme olarak görülmektedir.

Çalışmanın ana fikrinin pratikteki karşılığını görmek üzere bir araştırma yapılmıştır. Yapılan araştırma sınırlılıkları, yöntemi ve uygulaması açısından geliştirilmeye muhtaç olmasına karşın ilk değerlendirmeleri almak adına önem arz etmektedir. Araştırmanın, işletme yapıları birbirinden farklı olan sektörler için, sektör ayrımı yapmadan tüm sektörleri genellemesi, hedef kitlenin sadece büyük sanayi kuruluşları olması, hedeflenen evren büyüklüğünün gerisinde kalınması, anket yönteminin çalışma konularına yönelik doğru bir analiz için tam uygunlukta olmaması fark edilen yetersizlikleridir. Bu noktada muhasebe bilgi sisteminin bileşenleri ile kurumsal bilgelik anlayışının kriterlerine yönelik yapılacak uygulama, işletmeler özelinde hazırlanacak şablonlar ile daha spesifik ve nitel değerlendirmelere imkan taniyabilir. Uygulamalar periyodik olarak tekrarlanarak sistem üzerinde yapılan iyileştirmeler ve performans gözlemlenebilir. Sonuç itibariyle tamamen soyut olgular üzerine nitel değerlendirmeler ile kurgulanan çalışma yapılacak nicel uygulamalar ile somutlaştırılmaya çalışılmıştır.

Temel amacı, kurumsal bilgelik anlayışında bilgi yönetimini tekrar ele alarak, muhasebe bilgi sistemini bu altyapıda geliştirmek olan çalışma, yönetsel süreçlere daha fazla katkı yapan geleceğin muhasebe bakış açısını yansıtmaktadır. Muhasebe bilgi sisteminin formal bilgilerin yanı sıra informal bilgileri de kullanarak yönetsel ve stratejik kararlara destek olan, geleceğe dönük fikir veren raporlar üretebilmesinin anahtarını işaret etmektedir. Rekabetçi ve sürdürülebilir büyüme hedefleri doğrultusunda kurumsal bilgelik anlayışı, muhasebenin bilge bir sisteme ulaşmasını sağlayacak kritik bir çıkış yolu olarak görülmektedir.

\section{KAYNAKLAR}

Alagöz Ali- Ortakarpuz Metehan - Ceran Mehmet Burak, (2013), “Dynamic Capabilities of Enterprises İn Accounting Perspective And Evaluation of The Scope of Ias 38 Intangible Assets Standard", Proceedings of Annual Paris Business And Social Science Research Conference, Paris, France, 4 - 5 July.

Alagöz Ali- Öge Serdar - Koçyiğit Nezahat, (2013), "Muhasebe Bilgi Sistemi ve Karar Destek Sistemleri İlişkisinin Yönetsel Karar Alma Faaliyetlerine Etkisi” Selçuk Üniversitesi, Sosyal Bilimler Enstitüsü Dergisi, Sayı 30, ss. 27-40.

Alagöz Ali- Öge Serdar - Ortakarpuz Metehan, (2014), "Bir Kurumsal Zekâ Teknolojisi Olarak Veri Madenciliği ile Muhasebe Bilgi Sistemi İlişkisi”, Selçuk Üniversitesi, Sosyal Bilimler Enstitüsü Dergisi, Dr. Mehmet Yıldız Özel Sayıs1, ss.1-21. 
Anameriç Hakan, (2005), "Yönetim Bilgi Sistemlerinin Yönetim Fonksiyonları Üzerine Etkisi”, Ankara Üniversitesi Dil Ve Tarih-Coğrafya Fakültesi Dergisi, Vol. 45, N. 2, ss. 25-44.

Barutçugil İsmet, (2002), “Bilgi Yönetimi”, Kariyer Yayıncılık, İstanbul

Baykal Abdullah, (2006), Veri Madenciliği Uygulama Alanları, D.Ü.Ziya Gökalp Eğitim Fakültesi Dergisi 7, ss.95-107.

Bierly, Paul.E III.- Kessler Eric, H.- Christensen Edward, W. (2000). “Organizational Learning, Knowledge And Wisdom”, Journal Of Organizational Change Management, Vol.13 No.6, pp.595-618.

Boundless, (2015), “Management Levels: A Hierarchical View.” Boundless Business. boundless, https://www.boundless.com/business/textbooks/boundless-BusinessTextbook/Management-8/Types-Of-Management-61/Management-Levels-AHierarchical-View-293-7468/ (12.10.2015).

Ceylan Adnan- Kesim Halit - Eren Şule, (2005), "Dönüşümcü Ve Etkileyici Liderlik ile Örgütsel Bağlılık Arasındaki İlişkilere Yönelik Bir Araştırma”, Yönetim, Yıl: 16 Sayı: 51, ss. 32-42.

Coşan Pınar E. - Gülova Asena A. (2014), “Örgütsel Demokrasi”, Yönetim Ve Ekonomi, Cilt:21 Say1:2, ss.231-248.

Çelik Orhan, (2007), "İşletmelerde Muhasebe Bilgisi Ve Şirket Demokrasisi”, Ankara: Siyasal Kitabevi.

Chong S.- Choi Y.S., (2005). "Critical Factors In The Successful Implementation Of Knowledge Management “, Journal Of Knowledge Management Practice, June.

Davenport T.- De Long D.- Beers M., (1998). "Successful Knowledge Management Projects”. Sloan Management Review, Vol.39 No.2, pp.43-57.

Dinçer Ömer, (1992), “Stratejik Yönetim ve İşletme Politikası”, Alfa Yayınları, İstanbul.

Erçetin Şule, (2000) “Lider Sarmalında Vizyon”, Ankara: Nobel Yayıncılık.

Garvin David A. (1993), "Building A Learning Organization.” Harvard Business Review, Vol.71, Nr., pp. 78-91.

Gupta Jatinder N. D. (Ed.), (2003). “Creating Knowledge Based Organizations”, Hershey, Pa, Usa: Idea Group Publishing.

Hays J. (2007). “Dynamics Of Organisational Wisdom”, The Business Renaissance Quarterly, Vol.2, Issue 4, pp.17-35.

Intezari A.- Pauleen D. J., (2014). "Management Wisdom In Perspective: Are You Virtuous Enough To Succeed In Volatile Times?”, Bus Ethics, Vol.120 pp. 393-404. 
Karakoçak Kemal, (2007). "Bilgi Yönetimi Ve Verimliliğe Etkisi: Türkiye Büyük Millet Meclisi Uygulaması”, Ankara Üniversitesi Sosyal Bilimler Enstitüsü, Doktora Tezi.

Kaygisiz Esra - Çağliyan, Vural, (2014), "Bilgi Yönetimi ve Örgütsel Bilgelik İlişkisi Üzerine Sektörel Bir Değerlendirme: Metal Ve Makine Sanayi Örneği”, Selçuk Üniversitesi Sosyal Bilimler Enstitüsü Dergisi Vol.31, ss.227-240.

Kessler Eric, H.(2006). “Organizational Wisdom: Human, Managerial, And Strategic Implications”, Group And Organization Management, Vol.31-3, pp.296-299.

Kuşat Nurdan, (2012), "Sürdürülebilir İşletmeler İçin Kurumsal Sürdürülebilirlik ve İçsel Unsurlar1, Afyon Kocatepe Üniversitesi, İİBF Dergisi, Cilt: 14,Say1: 2, ss.227-242.

Lee Jang H.,- Kim Young G., (2001). “A Stage Model Of Organizational Knowledge Management: A Latent Content Analysis”, Expert Systems With Applications, Vol.20,pp.299-311.

Limas M. J. (2004). “Organizatonal Wisdom: Scale Development And Validtiy Assessment”, The Degree Of Doctor Of Industrial/Organizational Psychology. University Of Tulsa.

Moffet S., Mcadam R. - Parkinson S., (2003). “An Empirical Analysis Of Knowledge Management Applications.” Journal Of Knowledge Management, Vol.7 No.3, pp.626.

Nonaka Ikijuro, (1994) “A Dynamic Theory of Organizational Knowledge Creation” Organisation Science, Vol:5, No:1.

Pitkänen Hanna - Lukka Kari, (2010), “Formal and Informal Feedback In Management Accounting”, Chartered Institute of Management Accountants, Research Executive Summary Series, Volume 6, Issue 14.

Popadiuk S. - Choo C.W., (2006). "Innovation An Knowledge Creation: How Are These Concepts Related?”, International Journal Of Information Management, Vol.26 Issue 4, pp.302-312

Rahman, Mohd S.,A., (2008), "Utilisation of Data Mining Technology Within The Accounting Information System İn The Public Sector: A Country Study - Malaysia”, School of Accounting and Corporate Governance Faculty of Business University of Tasmania.

Ryan S.D. - Prybutok V. R., (2001). "Factors Affecting Knowledge Management Technologies: A Discriminative Approach”. Journal Of Computer Information Systems, Vol.41, No.3, pp.31-37.

Scott, Findlay, S. - Estabrooks, C. A.,(2006), "Mapping The Organizational Culture Research İn Nursing: A Literature Review", Journal of Advanced Nursing.

Sezgin Murat - Bulut Beyza, (2013), “ Örgüt Kültürü ve Halkla İlişkiler” Karabük Üniversitesi Sosyal Bilimler Enstitüsü Dergisi 3 (2), ss.182-194. 
Smith Michael P., (1976) "Barries To Organizational Democracy In Public Administration” Administration \& Society, Vol.: 8 (3), ss. 275-317.

Spiller, C. P. E.- Erakovic, L. - Henare, M. (2011). "Wise Up: Creating Organizational Wisdom Through An Ethic Of Kaitiakitanga”, Bus Ethics, No.104, pp.223-235.

Sürmeli Fevzi (Editör), Sürmeli Fevzi, Erdoğan Nurten, Erdoğan Melih, Banar Kerim, Kaya Ergün, Sevim Adnan (Bölüm Yazarları), (2005), "Muhasebe Bilgi Sistemi”, Anadolu Üniversitesi Yayın No:1644, Eskişehir.

Thierauf Robert J., (1999). “Knowledge Management Systems For Business”, British Library Cataloguing In Publication Data, USA.

Thierauf Robert J. - Hoctor James J., (2006). “Optimal Knowledge Management: Wisdom Management System Concepts And Applications”, Idea Group Publishing, USA\&UK.

Turan Aygül, (2014), “Temel Yetenek ve Dış Kaynaklardan Yararlanma Tekniklerine Felsefi Bir Bakış: Dinamik Beceriler ve İş Modeli Yaklaşımlarıyla İlişkilendirme”, KAU İİBF Dergisi, 5(7), ss. 147-170.

Tüm Kayahan, (2014), "Kurumsal Sürdürülebilirlik ve Muhasebeye Yansımaları: Sürdürülebilirlik Muhasebesi”, Akademik Yaklaşımlar Dergisi, Bahar 2014 Cilt: 5 Sayı:1 ss.58-81

Wilkinson Joseph W.- Wilkinson, Cerullo Michael J.- Raval Vasant, Wong - On-Wing Bernard, (2000), “Accounting Information Systems: Essential Concepts and Applications” The Study Of Accounting Information System Slides, Fourth Edition, John Wiley \& Sons, Inc. http://www.wiley.com/college/acc/wilkinson253529/Site/ppt/Ch_01.ppt (10.10.2015).

Yaghoubi N. Mohammad- Salehi Mahdi - Nezhad E. Behtari, (2011), "Relationship Between Tactical Processes of Knowledge Management And Organizational Intelligence: Iranian Evidence”, World Applied Sciences Journal, 12 (9) pp. 1413-1421.

Yazıcıoğlu Yahşi- Erdoğan Samiye, (2004), "SPSS Uygulamalı Bilimsel Araştırma Yöntemleri”, Ankara, Detay Yayıncılık. 
